\title{
Ontogeny and Cross-species Comparison of Pathways Involved in Drug Absorption, Distribution, Metabolism, and Excretion in Neonates (Review): Kidney
}

\author{
Ruud Bueters, DAn Bael, Elke Gasthuys, Connie Chen, Michiel F. Schreuder, \\ and Kendall S. Frazier
}

Janssen Research \& Development, a division of Janssen Pharmaceutica NV, Division of Discovery, Product Development \& Supply, Department of Nonclinical Safety, Beerse, Belgium (R.B.); ZNA Queen Paola Children's Hospital, Department of Pediatric Nephrology, Antwerp, Belgium (A.B.); Department of Paediatrics, Faculty of Medicine, Ghent University, Gent, Belgium (E.G.); Health and Environmental Sciences Institute, Washington, DC (C.C.); Radboudumc Amalia Children's Hospital, Department of Pediatric Nephrology, Nijmegen, The Netherlands (M.F.S.); and GlaxoSmithKline, Collegeville, Pennsylvania (K.S.F.)

Received October 18, 2019; accepted February 4, 2020

\section{ABSTRACT}

The kidneys play an important role in many processes, including urine formation, water conservation, acid-base equilibrium, and elimination of waste. The anatomic and functional development of the kidney has different maturation time points in humans versus animals, with critical differences between species in maturation before and after birth. Absorption, distribution, metabolism, and excretion (ADME) of drugs vary depending on age and maturation, which will lead to differences in toxicity and efficacy. When neonate/ juvenile laboratory animal studies are designed, a thorough knowledge of the differences in kidney development between newborns/ children and laboratory animals is essential. The human and laboratory animal data must be combined to obtain a more complete picture of the development in the kidneys around the neonatal period and the complexity of ADME in newborns and children. This review examines the ontogeny and cross-species differences in ADME processes in the developing kidney in preterm and term laboratory animals and children. It provides an overview of insights into ADME functionality in the kidney by identifying what is currently known and which gaps still exist. Currently important renal function properties such as glomerular filtration rate, renal blood flow, and ability to concentrate are generally well known, while detailed knowledge about transporter and metabolism maturation is growing but is still lacking. Preclinical data in those properties is limited to rodents and generally covers only the expression levels of transporter or enzyme-encoding genes. More knowledge on a functional level is needed to predict the kinetics and toxicity in neonate/juvenile toxicity and efficacy studies.

\section{SIGNIFICANCE STATEMENT}

This review provides insight in cross-species developmental differences of absorption, distribution, metabolism, and excretion properties in the kidney, which should be considered in neonate/juvenile study interpretation, hypotheses generation, and experimental design.
Introduction

The kidneys play a pivotal role in a number of processes, including 1) urine formation; 2) conservation of water, cations, anions, glucose, amino acids; and 3) elimination of endogenous and exogenous waste compounds (Gans and Mercer, 1984). These various functions are

https://doi.org/10.1124/dmd.119.089755. dependent on the specialized subcellular structural and functional properties of renal tubule epithelium, including their various transporters, metabolic activity, and membrane integrity. Therefore, the development and maturation of these processes in pediatric patients or in animals can have a profound effect on the disposition and fate of administered drug therapies that depend on the kidney for filtration, uptake, secretion, and/or metabolism.

ABBREVIATIONS: ADME, absorption; distribution; metabolism, and excretion; ATP, adenosine triphosphatel; BCRP, breast cancer resistance protein; BW, body weight; ENT, equilibrative nucleoside transporter; GFR, glomerular filtration rate; GST, glutathione S-transferase; GW, gestational weeks; KW, kidney weight; LDF, laser Doppler flowmetry; MATE, multidrug and toxin extrusion; MRI, Magnetic resonance imaging; mRNA, Messenger RNA; MRP, multidrug resistance-associated proteins; NPT, sodium-phosphate cotransporters; OAT, organic anion transporters; OATP, organic-anion-transporting polypeptide; OCT, organic cation transporters; OCTN, organic cation novel transporter; P450, cytochrome P450; PAH, para-aminohippurate; PAPS, 3'-phospoadenosine-5'-phosphosulfate; Pept, peptide transporter; Pgp, P-glycoprotein; PK, pharmacokinetics; PND, postnatal day; PNW, postnatal week; PXR, pregnane X receptor; RBF, renal blood flow; RPF, renal plasma flow; SCP, sulphachlorpyridazine; SLC, solute carrier; SULT, sulfotransferase; TmPAH, maximum tubular secretory capacity of PAH; UGT, uridine 5'diphospho-glucuronosyltransferase; URAT, urate transporter. 
The anatomic and functional development of the kidney has different maturation time points in man compared with laboratory animals. In addition to the knowledge of kidney development in humans, several reviews have been published on the comparative ontogeny of the developing kidney in different laboratory animals, which describe critical species differences in renal development and functional maturation before and after birth (Owen and Heywood, 1986; Witte et al., 1986; Zoetis and Hurtt, 2003; Solhaug et al., 2004; McMahon, 2016; Frazier, 2017).

Factors in the neonatal kidney that influence absorption, distribution, metabolism, and excretion (ADME) properties of drugs include renal blood flow (RBF), glomerular filtration rate (GFR), and the tubular mass and lack of tubule maturity, with its impact on tubular secretion and absorption, maintenance of acid-base equilibrium, and urineconcentrating mechanisms. These functions are all reduced in the juvenile animal (Seely, 2017). In addition, the ontogeny of metabolizing enzymes, transporters, and transcription factors in the kidney all play a major role. Better understanding of these factors is needed to improve prediction of the ADME characteristics of drugs and chemicals administered to neonates. There are numerous examples of drugs that behave quite differently in adults and neonates that can be explained by the lack of maturation of various transporters or metabolic enzymes such as propofol, pazopanib, or dabrafenib, among many others (Groseclose et al., 2015; Frazier, 2017; Michelet et al., 2018; Frazier et al., 2019).

The aim of the current review is to provide an overview of the ontogeny and cross-species differences of pathways involved in ADME in the developing kidney in preterm and term neonatal animals and children. This review is part of a multisector collaborative research effort coordinated by the Health and Environmental Sciences Institute to increase the knowledge base in the nonclinical space to better inform clinical treatment decisions made for the pediatric population (De Schaepdrijver et al., 2019; Hausner et al., 2019; Neal-Kluever et al., 2019). The ontogeny and cross-species differences of ADME-related processes in the liver and other organs will be covered by other reviews. These manuscripts will provide a comprehensive overview of available data and insights on ADME functionality present in the maturing organs, to toxicologists, modelers, and clinicians, by identifying what is currently known and which gaps still exist.

Laughon et al. (2014) stated that "Children are therapeutic orphans." Currently, pediatric therapeutic guidelines are supported by a limited number of trials performed in pediatric populations in combination with extrapolation from adult trials or case reports. The statement is also supported by the daily experience of clinicians, whereby a lack of "pediatric-adapted" drug information frequently requires off-label prescription of drugs, potentially leading to adverse events and dosage errors (Laughon et al., 2014; Skinner, 2014; Cuzzolin and Agostino, 2016). Over the last 10-20 years, an upsurge in pediatric drug research has been noted, partly based on legislative initiatives, leading to more pediatric labeling of drugs. Unfortunately, even with the increased regulatory efforts, still $>50 \%$ of the drugs used in the pediatric population and even $>75 \%$ of the drugs used in the critically ill and neonates are unlicensed or prescribed off-label (Cuzzolin and Agostino, 2016). Most common drug classes are antiinfectives, respiratory drugs, antianemics, cardiovascular, central nervous system drugs, and gastrointestinals (Cuzzolin and Agostino, 2016). Therefore, an improvement of current pediatric drug research conduct is required to attain information on age-appropriate dosage schemes, potential toxicity and adverse events. Extensive studies in the pediatric population are ethically not possible, whereby alternative approaches such as juvenile animal models and modeling and simulation tools emerge. The development and selection of appropriate juvenile animal models is key to build translatable models and to predict the effect on neonates and children based on juvenile animal in vivo data. To be able to perform this selection, a thorough cross-species knowledge of the morphologic and functional development of all organs involved in pharmacokinetics (PK), pharmacodynamics, and toxicity is needed.

To assess and incorporate the vast amount of disparate data across species on this topic, a thorough literature search was performed in PubMed/Medline, Web of Science, and Embase databases using a comprehensive list of keywords related to maturation of the kidney and the role of the kidney in the ADME processes. Additionally, previously published search strategies on kidney transporter ontogeny (Brouwer et al., 2015) were repeated and modified to include additional transporters, enzymes, and species. The literature search was limited to peer-reviewed English language articles. The review was centered around humans and the most predominant used toxicology laboratory animal species, namely, rat, mouse, dog, pig, and monkey. All species were assessed for each parameter. When information is not listed for a particular parameter, it indicates that no supporting data were found in our search. No additional animal or clinical experiments were performed for the construction of this review paper.

\section{Anatomic Development}

Nephrogenesis. In 2017, a comparison of nephrogenesis by species was presented in detail by Frazier (2017) and included review of earlier authors (Owen and Heywood, 1986; Witte et al., 1986; Zoetis and Hurtt, 2003; Solhaug et al., 2004; Cappon and Hurtt, 2010; McMahon, 2016). An overview of renal development and the nephrogenesis of the different species can be found in Table 1. The three main phases of in utero renal development include pronephros, mesonephros, and metanephros, with the latter forming the functioning kidney in vertebrates (Seely, 2017). Kidney formation involves a well-regulated balance between proliferation, differentiation, apoptosis, and morphogenesis (Frazier, 2017). Nephrogenesis, which involves the final phases of kidney development and tubule differentiation, occurs in very different contexts between species (McMahon, 2016). In humans, morphologic renal development occurs exclusively in utero, with nephrogenesis and organogenesis occurring from gestational week (GW) 6-36. After GW 36 , nephrogenesis is complete and each kidney has a full complement of nephrons (Solhaug et al., 2004). Though nephrogenesis begins in the fetus and is completed in humans before birth, it continues postnatally in the rat and is not completed until postnatal day (PND) 11-15 (Zoetis and Hurtt, 2003). In mice, most nephrons are fully formed by the end of gestation based on histomorphology (Zoetis and Hurtt, 2003; Frazier, 2017). In contrast, evidence in mice indicating labeled progenitor cells do not disappear until a few days after birth suggests nephrogenesis is not complete in mice until PND 2-4 (Short et al., 2014; McMahon, 2016). Furthermore, evidence from embryonic gene expression indicates that branching of the tips of renal tubules does not cease until PND 2 in mice (Short et al., 2014). In contrast, nephrogenesis is completed by GW 24 in most nonhuman primates (Frazier, 2017). Nephrogenesis in the dog and the pig proceeds approximately up to postnatal week (PNW) 2 and 3, respectively (Friis, 1980; Kleinman, 1982; Zoetis and Hurtt, 2003; Gasthuys et al., 2016).

Postnatal maturation and growth of nephron segments encompassing tubule elongation continues throughout the 1st year in human infants and lasts up to 5 months postnatally in nonhuman primates. Tubule differentiation occurs up to PND 21 in rats but is completed around the time of birth in mice (McMahon, 2016; Frazier, 2017). Tubule elongation in rodents slows considerably after PND 28. In dogs, the volume of nephron segments continues to grow from PNW 2 (when nephrogenesis ceases) to approximately PNW 28, enlarging by as much as 300\% (Eisenbrandt and Phemister, 1979). 
TABLE 1

Completion of nephrogenesis and vasculogenesis of different species

\begin{tabular}{|c|c|c|}
\hline Species & Nephrogenesis & Vasculogenesis \\
\hline $\operatorname{Human}^{a}$ & GW 36 & GW 34-36 \\
\hline Rat & PND 11-15 & PND 17-19 \\
\hline Mice & PND $2-4$ & PND 7 \\
\hline Dog & PNW 2 & PNW 6 \\
\hline Nonhuman primates $^{a}$ & GW 24 & By birth \\
\hline Pig & PNW 3 & PNW 8-12 \\
\hline
\end{tabular}

${ }^{a}$ Average gestational period is $40 \mathrm{wk}$ in human and $23-34 \mathrm{wk}$ in nonhuman primates (depending on specific species).

Vasculogenesis. In concert with nephrogenesis, human vasculogenesis is completed by GW 34-36. Vascular maturation in the kidney of nonhuman primates is also completed by birth. In dogs it is not completed until PNW 6. In rats, renal vasculogenesis is active as late as PND 12 and is not completed until PND 17-19, whereas in mice, it is complete by PND 7 (Frazier, 2017).

Kidney Size. The neonatal kidney in all species is smaller than the adult kidney and will increase in mass during the juvenile and pediatric growth period specific for that species (Frazier, 2017). It should be noted that the number of glomeruli is constant in an individual between the end of nephrogenesis and maturity, with the increase in renal volume attributable to an increase in tubular mass (Frazier, 2017). The lower tubular mass in juvenile kidneys results in diminished capacity for water and solute reabsorption and an increased risk of dehydration in neonates as compared with adults (Frazier, 2017).

In mice, the glomerular size relative to total kidney weight $(\mathrm{KW})$ is smaller than in other species, including rat. Glomerular size tends to increase with age and can vary among strains of rodents (Frazier et al., 2012). Takasu et al. (2015) evaluated the kidney size of microminipigs (Fuji Micra Inc.) (4-7 months of age) and beagle dogs (10 months of age). The kidney size (in cubic centimeter) was comparable between the dogs and the 7-month-old pigs (right kidney: 27.9-34.9; left kidney: 28.0-41.1) when both species were approximately the same size. The kidney size of a Hanford miniature swine (BW: $25 \mathrm{~kg})$ is $11 \times 6 \times 3 \mathrm{~cm}$ (KW: $120 \mathrm{~g}$ ), which resembles the kidney of a 70-kg human (Swindle and Brown, 2016).

\section{Functional Development}

Renal clearance encompasses three main processes: 1) glomerular filtration, 2) tubular secretion, and 3) active/passive tubular reabsorption. Functional maturation is closely related to the morphogenesis of the kidney. In all species, functional development lags behind anatomic maturation (Seely, 2017). During gestation, the homeostasis is mainly preserved by the placenta, whereas the contribution of the kidney starts to emerge in the third trimester (Chevalier and Norwood, 2011). Functional maturity is dependent on many factors. RBF, GFR, tubular secretion and absorption, maintenance of acid-base equilibrium, and urine-concentrating mechanisms are all limited in the juvenile animal. The reduced tubular mass and lack of tubule maturity in neonatal or juvenile kidneys are responsible for a reduced capacity to maintain kidney homeostasis. Full maturation differs per species and ranges from approximately 1 month in rodents to up to 2 years in humans.

Renal Blood Flow. RBF progressively increases during gestation and achieves full-term levels by GW 32-35 in humans. The values at term are less than those observed in adults even when corrected for BW, $\mathrm{KW}$, or body surface area. For the human kidney, the transition at birth is marked by striking physiologic functional changes that facilitate not only the immediate demands for adaptation to extra-uterine life but also the progressive maturation to adult renal function. The most striking postnatal transition occurs in an increase in RBF together with a marked change in glomerular filtration pressure, resulting in a rise in GFR. In contrast, urinary sodium output drops so that sodium, and thereby water, may be retained, which is needed for new tissue formation in this period of rapid somatic growth.

Renal blood flow and flow velocity have been determined in children and adolescents (range 1-16 years) by duplex Doppler and was shown to be 4.1 (S.D. 1.2) $\mathrm{ml} / \mathrm{min}$ per gram KW, independent of age (Grunert et al., 1990). Another study in healthy neonates resulted in an RBF of $21 \mathrm{ml} / \mathrm{min}$ per kilogram BW (Visser et al., 1992). More values have been reported for the effective renal plasma flow (RPF) at different developmental stages being $20 \mathrm{ml} / \mathrm{min}$ per $1.73 \mathrm{~m}^{2}$ in the premature infant, $45 \mathrm{ml} / \mathrm{min}$ per $1.73 \mathrm{~m}^{2}$ by GW $35,83 \mathrm{ml} / \mathrm{min}$ per $1.73 \mathrm{~m}^{2}$ in term infants, $300 \mathrm{ml} / \mathrm{min}$ per $1.73 \mathrm{~m}^{2}$ by toddler age, and up to a rate of $650 \mathrm{ml} / \mathrm{min}$ per $1.73 \mathrm{~m}^{2}$ by 2 years of age (Jose et al., 1994).

In rats, multiple protocols have been used over the years to measure RBF or RPF. Classically, methods started out to be indirect calculations via para-aminohippurate (PAH) clearance and evolved using surgical models with flow probes, transducers, or microspheres. More recently, magnetic resonance imaging (MRI) techniques and awake-instrumented models have been developed. Most research has focused on a time period in which RBF was already considered at its maximum capacity (>PND 20). Horster and Lewy (1970) showed that from PND 1-3, RPF decreased from 0.017 to $0.013 \mathrm{ml} / \mathrm{min}$ per gram $\mathrm{KW}$ by PAH clearance. At PND 24-28, RBF (as measured by radiolabeled microspheres) showed a flow of approximately $4.5 \mathrm{ml} / \mathrm{min}$ for an average $\mathrm{KW}$ of 0.52-0.55 g (Chevalier and Thornhill, 1995). In adult rats, wider ranges have been reported. Cortical RBF has been evaluated by arterial spin labeling MRI and showed ranges between 1.2 and $4.2 \mathrm{ml} / \mathrm{min}$ per gram KW (Liu et al., 2012; Zimmer et al., 2013; Tan et al., 2015; Romero et al., 2018). This method showed good correlations with PAH clearance in humans (Ritt et al., 2010). Additionally, it has been pointed out by other researchers that the microsphere method might lead to an overestimation of RBF (Prinzen and Bassingthwaighte, 2000). In 3- to 4-month-old Wistar rats, flow-probe instrumented conscious rats showed RBF rates ranging from 4.4 to $5.5 \mathrm{ml} / \mathrm{min}$ (Flemming et al., 2001). Even though a rough range of RBF in adult rats has been established, data for the first three PNW in rats are still lacking.

Just as in rats, different protocols have been used over the years to measure the $\mathrm{RBF}$ in mice. Adult male C57BL/6 mice have a PAH clearance of $6.3 \mathrm{ml} / \mathrm{min}$ per gram BW (Cervenka et al., 1999). In another study, PAH clearance in 14-month-old 129SV-C57BL/6 mice resulted in a mean RBF of $4.7 \mathrm{ml} / \mathrm{min}$ per gram (Cullen-McEwen et al., 2003). A surgical approach with flowmeters resulted in an RBF of $0.59 \mathrm{ml} / \mathrm{min}$ in 10- to 14-week-old C57BL/6J mice (Mergia et al., 2018). Adult New Zealand inbred mice showed a baseline RBF of $0.83 \mathrm{ml} / \mathrm{min}$ in freely moving conscious instrumented mice (Iliescu et al., 2008). There is variation in RBF results between different methods in adult mice. Data on the 1st weeks after birth are sparse, but Barnett et al. (2017) showed a rapid increase in renal perfusion from PND 0 [70 laser Doppler flowmetry (LDF) arbitrary units] to PND 3 (180 LDF arbitrary units) and PND 7 (280 LDF arbitrary units) in CD-1 mice.

More neonatal data are available for the dog. Renal perfusion flow was calculated in mongrel puppies from inulin clearance by Fick's law and ranged from $0.7 \mathrm{ml} / \mathrm{min}$ per gram $\mathrm{KW}$ on $\mathrm{PND} 1-1.8 \mathrm{ml} / \mathrm{min}$ per gram KW at 1 month of age compared with the adult reference of $2.7 \mathrm{ml} /$ min per gram KW (Kleinman and Lubbe, 1972). Another study was performed measuring RBF by xenon washout and krypton autoradiography in mongrel dogs aged 18 hours to 70 days by Aschinberg et al. (1975). They showed an increase in RBF from $0.39 \mathrm{ml} / \mathrm{min}$ per gram $\mathrm{KW}$ in week 1 to $2.1 \mathrm{ml} / \mathrm{min}$ per gram $\mathrm{KW}$ in week 6 , which is in the 
same order of magnitude (Aschinberg et al., 1975). A noteworthy detail here was that the increase in RBF appeared rather linear between week 1 and week 6. Another study in newborn mongrel dogs, but with a microsphere model, showed an $\mathrm{RBF}$ of $0.43 \mathrm{ml} / \mathrm{min}$ per gram $\mathrm{KW}$ for newborns, $2.1 \mathrm{ml} / \mathrm{min}$ per gram $\mathrm{KW}$ for 6-week old dogs, and $3.8 \mathrm{ml} /$ min per gram KW for adults (Olbing et al., 1973). These estimates were further confirmed by flow transducer experiments in 14- to 25-day-old mongrel puppies (RBF of $1.6 \mathrm{ml} / \mathrm{min}$ per gram $\mathrm{KW}$ ) and in adult dogs (RBF $3.7 \mathrm{ml} / \mathrm{min}$ per gram KW) (Baer and Navar, 1973; Jose et al., 1975). Again, more recently, RBF measurements can be performed in conscious flow-probe instrumented dogs, and flow rates of 214-310 ml/ min were registered in foxhounds weighing $23-35 \mathrm{~kg}$ by Just et al. (1998).

In pigs, experiments have been performed in 10- to 12-week-old animals both via microsphere and arterial spin labeling methodologies. Microsphere and arterial spin labeling MRI results were $3.7 \mathrm{ml} / \mathrm{min}$ per gram KW and 2.0-2.1 $\mathrm{ml} / \mathrm{min}$ per gram $\mathrm{KW}$, respectively (Artz et al., 2011). Additionally, microsphere experiments in piglets aged 6 hours to 45 days showed mean $\mathrm{RBF}$ increased from $43 \mathrm{ml} / \mathrm{min}$ per square meter body surface area to $760 \mathrm{ml} / \mathrm{min}$ per square meter (Gruskin et al., 1970). This large increase is mainly driven by the normalization to body surface area and the rapid growth rate of pigs.

For cynomolgus monkeys, RBF is at the maximum level at birth (Frazier, 2017). In rhesus monkeys between 3 and 5 days of age, RBF values of $2.5 \mathrm{ml} / \mathrm{min}$ per gram $\mathrm{KW}$ were determined by microsphere methodology (Moore et al., 1974). Another study in infantile rhesus monkeys showed an RBF of $3.5 \mathrm{ml} / \mathrm{min}$ per gram KW (Behrman and Lees, 1971). However adult rhesus monkeys showed higher normalized RBF values being 7.0-9.8 $\mathrm{ml} / \mathrm{min}$ per gram $\mathrm{KW}$, indicating that there may be differences in RBF maturation between species (Sivarajan et al., 1976).

Glomerular Filtration Rate. The GFR is widely used as a quantitative marker to assess renal clearance. In humans, GFR remains relatively low during gestation and increases quickly in the 1st weeks of life, after which it increases steadily and reaches adult levels at 1 to 2 years of age (Zoetis and Hurtt, 2003). During gestation, the increase in GFR is primarily attributed to nephrogenesis, which leads to an upsurge in new glomeruli. After birth, the rise in GFR is attributed to an increase in RBF, a higher capillary pressure, a drop in renal vascular resistance, and a rise in cardiac output (Gruskin et al., 1970). In clinical practice, GFR is most often estimated in humans, rather than measured precisely, using the Cockcroft-Gault equation, Chronic Kidney Disease Epidemiology Collaboration equation, the Modification of Diet in Renal Disease equation, the Schwartz equation (in children), or other formulas. Actual measured values for GFR and reference ranges can be problematic to compare across species. In humans, GFR is normalized to a body surface area of $1.73 \mathrm{~m}^{2}$ [once an average adult body surface area (BW): $70 \mathrm{~kg}$ ], and normal values represent approximately $20 \mathrm{ml} / \mathrm{min}$ per $1.73 \mathrm{~m}^{2}$ at birth, which increases to around $50 \mathrm{ml} / \mathrm{min}$ per $1.73 \mathrm{~m}^{2}$ by PNW 2 (Gomez et al., 1999; Vieux et al., 2010; Baum, 2016). Measured or estimated values of $100-120 \mathrm{ml} / \mathrm{min}$ per $1.73 \mathrm{~m}^{2}$ occur by 2 years of age and remain relatively constant into adulthood. Normalizing for BW results in a GFR of approximately $0.8 \mathrm{ml} / \mathrm{min}$ per kilogram shortly after birth (Wilkins, 1992), which increases to maximum values of approximately $3.2 \mathrm{ml} / \mathrm{min}$ per kilogram around the age of 2 to 3 years (Hayton, 2000). With increasing age, the GFR decreases to approximately $2.0 \mathrm{ml} /$ min per kilogram in adults (Hayton, 2000).

In dogs, reference ranges have not been definitively agreed upon, and variation in results have been reported in surveys of the GFR literature (Moe and Heiene, 1995). The primary reason why a reference range for GFR has not been produced is most likely due to variations in strains or protocols (i.e., markers used, assays for measurement of serum or urine marker concentration, urine or blood sampling times, and PK models used for GFR calculation) as well as other factors such as circadian variation, hydration status, dietary protein, and the use of sedation during measurement (Von Hendy-Willson and Pressler, 2011). Generally agreed upon values for normal GFR in the adult dog using several methods are approximately $3.7-4.3 \mathrm{ml} / \mathrm{min}$ per kilogram (Finco et al., 1993; Watson et al., 2002; Von Hendy-Willson and Pressler, 2011). At PND 1, puppies have only approximately one-fourth of this value at just under $1 \mathrm{ml} / \mathrm{min}$ per kilogram (Kleinman, 1982).

The variety of substrates and methods for determining the experimental value of GFR in laboratory rats have resulted in huge variances in published values, and the way in which they are expressed can also confuse readers. Using iothalamate and I-hippuran, values of approximately $1.0 \mathrm{ml} / \mathrm{min}$ per $100 \mathrm{~g}$ of BW were noted (Marcel de Vries et al., 1997). Using inulin clearance to assess GFR in experiments over 50 years ago, adult values were listed as $1.2 \mathrm{ml} / \mathrm{min}$ per gram of $\mathrm{KW}$ (van Liew et al., 1967). In neonatal Sprague Dawley rats, values of $0.044 \mathrm{ml} /$ min per gram $\mathrm{KW}$ at PND 3 were noted that increased to $0.3 \mathrm{ml} / \mathrm{min}$ per gram KW by PND 18 (Horster and Lewy, 1970; Horster, 1977). In a study using female Han Wistar rats, values for GFR were similar and reported as $1.2 \mathrm{ml} / \mathrm{min}$ per gram $\mathrm{KW}$ for adult rats and were only slightly lower at PND 28. These data indicate that GFR matures around PNW 4 in rats even though maximum values and complete maturation are not completed until PND 42 (Guron, 2005; Frazier, 2017). In recent years, a variety of new imaging modalities that can measure GFR transdermally or via MRI in animals has become available. A typical GFR value obtained using these methods is $2.4 \mathrm{ml} / \mathrm{min}$ in adult rats weighing approximately $229 \mathrm{~g}$ (Yu et al., 2007).

The small size of mice and their sensitivity to blood loss pose a challenge to clearance studies, which normally require sequential assessment of plasma concentrations of inulin and/or other substrates. In some studies, GFR has been assessed by using radioisotope-labeled inulin and in others by chromotropic detection (Field et al., 1991). The measured values for GFR for adult mice differ by strain, with lower values reported for C57BL mice. GFR averages 237 and $140 \mu \mathrm{l} / \mathrm{min}$ in adult male and female C57BL/6J mice, respectively, using bicompartmental analysis of inulin clearance. Other strains have reported GFR values between 0.8 and $1.4 \mathrm{ml} / \mathrm{min}$ per gram BW (Qi et al., 2004; Qi and Breyer, 2009). Similar values of $240 \mu \mathrm{l} / \mathrm{min}$ were obtained using highthroughput imaging techniques in CD-1 mice (Rieg, 2013). Using separate methodology, normal adult values of $1.0 \mathrm{ml} / \mathrm{min}$ per gram $\mathrm{BW}$ have also been published (Field et al., 1991). Because of logistical problems in obtaining values in neonatal mice, standard ranges are not available for mice younger than 2 weeks.

For minipigs, values for GFR are very hard to compare based on age because of the marked increase in BW over time. Glomerular filtration rate values of 44-58 ml/min have been noted in minipigs at PNW 4, which corresponds to approximately $4.5-5 \mathrm{ml} / \mathrm{min}$ per kilogram. By PNW 15, GFR has increased to $101-116 \mathrm{ml} / \mathrm{min}$, but as they have now grown significantly, the GFR value is down to $3-4 \mathrm{ml} / \mathrm{min}$ per kilogram, which is roughly similar to the dog on a BW basis (Ransley et al., 1987). For conventional pigs (Belgian landrace $\times$ large white), the GFR indexed to body surface area increased in GFR from 46.6 to $100.9 \mathrm{ml} /$ min per square meter from 8 days to 7 weeks of age (Gasthuys et al., 2017). Kaskel and Kleinman (1976) and Friis (1979) also measured the GFR in growing conventional piglets indexed to KW and BW. The maturation of the GFR in those studies was similar to the trends observed by Gasthuys et al. (2017).

In healthy adult cynomolgus macaque monkeys, the GFR was found to be $3.1 \mathrm{ml} / \mathrm{min}$ per kilogram by two separate methods by one group (Iwama et al., 2014) and 2.5-2.8 $\mathrm{ml} / \mathrm{min}$ per kilogram by another group using yet another method (Zhang et al., 2017). Similar values between 
2.8 and $4 \mathrm{ml} / \mathrm{min}$ per kilogram have been noted in adult rhesus macaques (Rabito et al., 2010), but precise values for GFR in monkeys in the first week after birth are not available.

Tubular Secretion. The renal tubules transfer substances, including drugs, to the urinary filtrate via tubular secretion. The level of maturation in the fetal and the juvenile kidney should be considered in drug administration because the drug excretion profile may undergo developmental changes. In general, the secretory capacity will increase as the kidney develops. Tubular secretory capacity can be measured via any one of a number of standard analytes but is difficult to assess prenatally. More practical physiologic assays in the postnatal period involve measuring excreted electrolytes directly in urine such as sodium or chloride to compare trends over time, but these analytes may only reflect concentrating ability rather than true excretion capacity, as electrolytes are also filtered. It is known that the fetal renin-angiotensin system is active in utero and maintains the fetal renal excretion of sodium and water into the amniotic cavity, aiding the maternal system and ensuring an adequate volume of amniotic fluid for normal growth and development (Lumbers, 1995). In rodents and other animals, fractional excretion rate of solutes and water changes as a function of age, and the urinary $\mathrm{Na}^{+} / \mathrm{K}^{+}$concentration ratio often drops significantly at the time of birth. Secretory capacity can be measured directly by analyzing compounds in urine, which are not filtered or absorbed. It must be stressed that each specific transporter will mature at its own pace and lifecycle, and thus a particular maximum secretory capacity or excretion rate will vary with the transporter that a compound is associated with. In practice, excretion rates can be measured for compounds that are both filtered and secreted, such as creatinine or PAH. Because PAH is efficiently transported by the organic anion transporter 1 (OAT1) in humans and animals, PAH can be used to measure the effective RPF and the maximum tubular secretory capacity (TmPAH) (i.e., the difference between the total rate of excretion and quantity filtered by the glomeruli), which for PAH, is primarily attributable to OAT1 activity (Momper and Nigam, 2018). Upregulation of OAT1 and OAT3 in the proximal tubules during the postnatal period is a critical factor in tubular secretory capacity in both humans and rodents (Momper and Nigam, 2018). More details on transporters can be found in the transporter section of the manuscript.

Values for maturation of excretion have been established for some species. Acquisition of filtration and secretion do not occur simultaneously. During the first months of life, the maximum tubular secretory capacity for organic anions is lower than GFR when compared with adults, and there is significant intersubject variability.

Human tubular secretory capacity in the kidney reaches maximum capacity at PNW 30 but is lowest in the 1st month of infancy (West et al., 1948). At PND 1-30 in humans, the TmPAH was shown to be only approximately $26 \%$ of the average during 1-12 years of age (Rubin et al., 1949). In rodents, secretory capacity appears to increase from birth to PND 28 as overall kidney function matures (Frazier, 2017). It should be stressed that tubular secretory capacity is not necessarily equivalent to GFR, as the rate of maturation in these processes is not identical within or among species.

Friis (1983) assessed the maturation of the active tubular secretion in conventional pigs by using PAH. Adult levels were reached at PNW 8 (PND 0-3: $0.8 \mathrm{ml} / \mathrm{min}$ per gram $\mathrm{KW}$ and $\mathrm{PNW} 8: 1.9 \mathrm{ml} / \mathrm{min}$ per gram KW). The TmPAH rose 4-fold from PND 0-3 to PNW 8.

Concentrating Capacity. The concentrating capacity of the kidney depends on the medullary depth of a specific species. Greater depths of medulla results in the kidney being able to concentrate urine to a greater osmolality (Gans and Mercer, 1984). The relative medullary thicknesses for various species are 3 for humans, 1.6 for pigs, 4.3 for dogs, and 5.8 for rats (Schmidt-Nielsen and O'Dell, 1961). Maturation of the concentrating capacity is shown in Table 2.
Other Functions. In humans, fetal urine formation starts during the first trimester of pregnancy (GW 10 to 11) (Abramovich, 1968). The hourly fetal urine production rate, estimated by regression analysis of bladder volumes, increases steadily during gestation (GW 20: $5 \mathrm{ml} / \mathrm{h}$ to GW 40: $51 \mathrm{ml} / \mathrm{h}$ ), whereas the bladder storage interval remains unchanged (7-43 minutes) (Fagerquist, 2012). The increase in hourly fetal urine production rate is attributed to nephrogenesis and dynamic changes in RBF, GFR, tubular function, and hormonal regulation (Chevalier and Norwood, 2011).

\section{Pharmacokinetic Characteristics}

Renal Transporter Maturation. The elucidation of transporter activity in various species, and especially humans, has become increasingly important in predicting drug-drug interactions and for understanding the mechanism of some renal toxicities (Ennulat et al., 2018). However, to date, developmental data on transporters in pediatric patients and transporter ontogeny in general remains a significant gap in our understanding (Brouwer et al., 2015; Momper and Nigam, 2018).

Most renal transporters are localized to the proximal tubules (Frazier and Seely, 2018). In 2015, a comprehensive review of transporter maturation in humans has been compiled by Brouwer et al. (2015). We extended this review, and the results are listed in Table 3, with localization shown in Fig. 1. In general, data are limited about transporter ontogeny in human and nonrodent kidneys because most kidney transporter characterization has been performed in rodents. However, a recent publication of Cheung et al. (2019) provides new insights on transporter maturation in humans using a more quantitative and novel technological approach with liquid chromatography-mass spectrometry. There are several important differences in species between renal transporter expression as well as in the timing of functional maturation of transport capacity (Sweeney et al., 2011). Transporter expression can be affected by both age and gender. In general, kidney transporters are largely immature at birth in humans and laboratory animals (Buist et al., 2002; Sweeney et al., 2011).

Among various transporters, the ATP-binding cassette and solute carrier (SLC) families are responsible for the transport of most of the drugs handled by the kidney. Among the apical membrane (efflux) transporters of the proximal tubule, P-glycoprotein (Pgp), also termed multidrug resistance protein 1 , is one of the most important for drug interactions. P-glycoprotein has been localized in human fetal kidneys by GW 5.5 using immunohistochemistry (Konieczna et al., 2011). Significant expression of Pgp has been demonstrated in humans at GW 11 in renal tubules and is present afterward throughout gestation, increasing after birth to peak levels as an adult (van Kalken et al., 1992; Miki et al., 2005; Brouwer et al., 2015; Cheung et al., 2019). Protein abundance of Pgp is, however, already at adult level during childhood (Cheung et al., 2019). Low levels of Pgp expression have been noted in fetal rat kidneys, increasing at gestation and up through the early development period to weaning, with maximum levels achieved

TABLE 2

Age at which full maturation of some physiologic functions of the kidney is attained

\begin{tabular}{lccc}
\hline & GFR & RBF & Concentrating capacity \\
\hline Human & PNW 52-104 & GW 32-35 & PNW 52 \\
Rat & PND 42 & PND 16-24 & PND 11 \\
Mice & PND 28-32 & PND 16-22 & PND 21 \\
Dog & PNW 8-10 & PND 12 & $<$ PND 1 \\
Nonhuman primate & PNW 26 & <ND 1 & PNW 20 \\
Pigs & PNW 8 & Unknown & Unknown \\
\hline
\end{tabular}

${ }^{a}$ One conventional pig. 
TABLE 3

Cross-species overview of renal drug transporters

Fetal-adult relations have not been described in nonhuman primates, dogs, and pigs.

\begin{tabular}{|c|c|c|c|c|}
\hline Transporter & Human & Mice & Rat & Reference(s) \\
\hline PGP & $\begin{array}{l}\text { Expression of PGP was noted from } \\
\text { GW 5.5. Significant expression } \\
\text { by GW } 11 \text { with increasing } \\
\text { expression after birth and in } \\
\text { adults. Protein abundance is } \\
\text { lowest in newborns (PND } \\
0-28) / \text { infants ( } 1-24 \text { mo) and } \\
\text { reached adult ( }>16 \text { yr) levels } \\
\text { during the child stage }(2-12 \mathrm{yr})\end{array}$ & $\begin{array}{l}\text { Pgp was marginally expressed in } \\
\text { newborns and was increased in } \\
\text { the postnatal period, with } \\
\text { a maximum expression on } \\
\text { PND } 21 \text {. At day } 45 \text {, there was } \\
\text { a decline in males but not } \\
\text { females. }\end{array}$ & $\begin{array}{l}\text { Expression was marginal at birth } \\
\text { and increased during postnatal } \\
\text { stage with highest levels } \\
\text { between PND 11-26. }\end{array}$ & $\begin{array}{l}\text { van Kalken et al., 1992; Miki et al., } \\
\text { 2005; Pinto et al., 2005; de Zwart } \\
\text { et al., 2008; Cui et al., 2009; } \\
\text { Konieczna et al., 2011; Sweeney } \\
\text { et al., 2011; Xu et al., 2017; Cheung } \\
\text { et al., } 2019\end{array}$ \\
\hline BCRP & $\begin{array}{l}\text { Significant expression was noted at } \\
\text { GW } 5.5 \text { and } 28 \text {. BCRP is } \\
\text { upregulated in the term newborn } \\
\text { and mostly reached adult levels } \\
\text { before } 2 \text { yr of age. Protein } \\
\text { abundance is, however, similar } \\
\text { between newborns and adults. }\end{array}$ & No fetal-adult relation described. & $\begin{array}{l}\text { Expression was increased during } \\
\text { postnatal stage compared with } \\
\text { prenatal stage. During the } \\
\text { postnatal stage, expression was } \\
\text { remained stable and highest } \\
\text { expression was present in the } \\
\text { adult stage. }\end{array}$ & $\begin{array}{l}\text { de Zwart et al., 2008; Konieczna et al., } \\
\text { 2011; Sweeney et al., 2011; Xu et al., } \\
\text { 2017; Cheung et al., } 2019\end{array}$ \\
\hline MRP1 & $\begin{array}{l}\text { Significant expression was noted at } \\
\text { GW } 5.5 \text { and } 28 \text {. }\end{array}$ & $\begin{array}{l}\text { MRP1 was expressed at adult } \\
\text { levels at birth. Female } \\
\text { expression was predominant. }\end{array}$ & $\begin{array}{l}\text { MRP1 was most highly expressed } \\
\text { at birth. }\end{array}$ & $\begin{array}{l}\text { Maher et al., 2005; de Zwart et al., } \\
\text { 2008; Konieczna et al., } 2011\end{array}$ \\
\hline MRP2 & $\begin{array}{l}\text { MRP2 shows similar gene } \\
\text { expression levels from } \\
\text { prematures (PND 0-28, GW } \\
<37 \text { ) up until adult stages. }\end{array}$ & $\begin{array}{l}\text { MRP2 levels was increased over } \\
\text { time to reach adult levels } \\
\text { during the } 1 \text { st weeks of life. }\end{array}$ & $\begin{array}{l}\text { Expression was increased in the } \\
\text { postnatal stage compared with } \\
\text { prenatal stage. During the } \\
\text { postnatal stage, expression was } \\
\text { remained stable, but protein was } \\
\text { increased and highest expression } \\
\text { was presented in the mature } \\
\text { stage. }\end{array}$ & $\begin{array}{l}\text { Maher et al., 2005; de Zwart et al., } \\
\text { 2008; Sweeney et al., 2011; Nomura } \\
\text { et al., 2012; Cheung et al., } 2019\end{array}$ \\
\hline MRP3 & No fetal-adult relation described. & $\begin{array}{l}\text { MRP3 levels were generally } \\
\text { increased over time to reach } \\
\text { adult levels. Female expression } \\
\text { was predominant. }\end{array}$ & $\begin{array}{l}\text { MRP3 was most highly expressed } \\
\text { at birth. }\end{array}$ & Maher et al., 2005; de Zwart et al., 2008 \\
\hline MRP4 & $\begin{array}{l}\text { MRP4 shows similar gene } \\
\text { expression levels from } \\
\text { prematures up until adult stages. }\end{array}$ & $\begin{array}{l}\text { MRP4 levels were generally } \\
\text { increased over time to reach } \\
\text { adult levels. Female expression } \\
\text { was predominant. }\end{array}$ & $\begin{array}{l}\text { Stable expression during fetal and } \\
\text { early postnatal development. } \\
\text { Higher expression in adult state. }\end{array}$ & $\begin{array}{l}\text { Maher et al., 2005; Sweeney et al., } \\
\text { 2011; Nomura et al., 2012; Xu et al., } \\
\text { 2017; Cheung et al., } 2019\end{array}$ \\
\hline $\begin{array}{l}\text { OATP1A2 } \\
\text { (rodent } \\
\text { analogs } \\
\text { OATP 1, } \\
\text { 3-6) }\end{array}$ & No fetal-adult relation described. & $\begin{array}{l}\text { OATP1A1 was hardly present at } \\
\text { birth and showed high } \\
\text { expression on PND } 45 \text { in males } \\
\text { but not females. OATP1A4 } \\
\text { showed stable expression from } \\
\text { PND } 2 \text { to } 45 \text {. OATP1A6 } \\
\text { expression started to increase } 2 \\
\text { wk after birth. }\end{array}$ & $\begin{array}{l}\text { OATP1A4 peak levels were } \\
\text { reached in the 1st week of birth } \\
\text { and were then slowly decreased } \\
\text { toward adult levels. }\end{array}$ & Cheng et al., 2005; de Zwart et al., 2008 \\
\hline OCT1 & No fetal-adult relation described. & $\begin{array}{l}\text { OCT1 expression was low before } \\
\text { birth and was gradually } \\
\text { increased in the first two PNW } \\
\text { and peaked at PND 22, after } \\
\text { which it remained rather stable. }\end{array}$ & $\begin{array}{l}\text { OCT1 expression was increased } \\
\text { from late prenatal development } \\
\text { up until adult stage. Overall } \\
\text { expression was only limited at } \\
\text { birth. }\end{array}$ & $\begin{array}{l}\text { Slitt et al., 2002; Alnouti et al., 2006; de } \\
\text { Zwart et al., 2008; Sweeney et al., } \\
\text { 2011; Ahmadimoghaddam et al., } \\
\text { 2013; Xu et al., } 2017\end{array}$ \\
\hline OCT2 & $\begin{array}{l}\text { Gene expression is lowest in the } \\
\text { preterm newborn and reaches } \\
\text { adult levels before } 2 \text { yr of age. } \\
\text { Protein abundance starts to } \\
\text { reach adult levels in the child } \\
\text { stage. }\end{array}$ & $\begin{array}{l}\text { OCT } 2 \text { was undetected before } \\
\text { birth, had a stable expression } \\
\text { after birth, and was increased } \\
\text { somewhat at PND } 22 \text {. From } \\
\text { PND } 30 \text { onward, expression } \\
\text { increased sharply in males but } \\
\text { remained unchanged in } \\
\text { females. }\end{array}$ & $\begin{array}{l}\text { OCT2 was slightly increased from } \\
\text { the prenatal phase on but } \\
\text { showed significantly increased } \\
\text { expression at maturity. }\end{array}$ & $\begin{array}{l}\text { Slitt et al., 2002; Alnouti et al., 2006; } \\
\text { Sweeney et al., 2011; Xu et al., 2017; } \\
\text { Cheung et al., } 2019\end{array}$ \\
\hline OAT1 & $\begin{array}{l}\text { OAT1 expression is lowest in } \\
\text { preterm newborns and reaches } \\
\text { adult levels at term birth or in } \\
\text { infants. Protein abundance is } \\
\text { lowest in term newborns and } \\
\text { infants; levels in children and } \\
\text { adolescents (12-16 yr) were } \\
\text { approaching adult levels. }\end{array}$ & $\begin{array}{l}\text { Expression was noted on day } 15 \\
\text { of gestation and was increased } \\
\text { progressively toward } \\
\text { adulthood. Organ culture } \\
\text { showed positive transport } \\
\text { activity. }\end{array}$ & $\begin{array}{l}\text { OAT1 expression was increased } \\
\text { during prenatal development, } \\
\text { remained stable at postnatal } \\
\text { development, and was increased } \\
\text { again at the mature age. }\end{array}$ & $\begin{array}{l}\text { Lopez-Nieto et al., 1997; Nakajima } \\
\text { et al., 2000; Pavlova et al., 2000; de } \\
\text { Zwart et al., 2008; Truong et al., } \\
\text { 2008; Hwang et al., 2010; Nagle } \\
\text { et al., 2011; Sweeney et al., 2011; } \\
\text { Nomura et al., 2012; Xu et al., 2017; } \\
\text { Cheung et al., } 2019\end{array}$ \\
\hline OAT3 & $\begin{array}{l}\text { OAT3 expression is lowest in the } \\
\text { preterm newborn and reaches } \\
\text { adult levels before } 2 \mathrm{yr} \text { of age. } \\
\text { Protein abundance was lowest in } \\
\text { term and newborn infants and } \\
\text { rose to adult levels in the } \\
\text { adolescent stage. }\end{array}$ & $\begin{array}{l}\text { OAT3 was detected on day } 14 \text { of } \\
\text { gestation, and expression was } \\
\text { gradually increased up to } \\
\text { adulthood. }\end{array}$ & $\begin{array}{l}\text { OAT3 expression was increased } \\
\text { during the late prenatal } \\
\text { development and kept increasing } \\
\text { until a mature age. }\end{array}$ & $\begin{array}{l}\text { Pavlova et al., 2000; Buist and } \\
\text { Klaassen, 2004; Hwang et al., 2010; } \\
\text { Sweeney et al., 2011; Nomura et al., } \\
\text { 2012; Xu et al., } 2017\end{array}$ \\
\hline
\end{tabular}


TABLE 3-Continued

\begin{tabular}{|c|c|c|c|c|}
\hline Transporter & Human & Mice & Rat & Reference(s) \\
\hline OCTn1 & No fetal-adult relation described. & $\begin{array}{l}\text { Expression was almost absent on } \\
\text { PND -2, was gradually } \\
\text { increased PNW 1, and doubled } \\
\text { at PNW 2. From PNW 3, it } \\
\text { increased again, reaching } \\
\text { maximum values around PND } \\
40\end{array}$ & $\begin{array}{l}\text { OCTn1 showed } 100 \text {-fold lower } \\
\text { expression compared with adult } \\
\text { levels at gestational day } 13 \text {, and } \\
\text { levels started to increase at } \\
\text { gestational day } 18 \text {. Most } \\
\text { pronounced upregulation was } \\
\text { present in PNW } 1 \text { and PNW } 4 \text {. }\end{array}$ & $\begin{array}{l}\text { Slitt et al., 2002; Alnouti et al., 2006; } \\
\text { Sweet et al., 2006; Sweeney et al., } \\
2011\end{array}$ \\
\hline OCTn2 & No fetal-adult relation described. & $\begin{array}{l}\text { Very low expression at PND -2, } \\
\text { which was increased } \\
\text { pronouncedly at PNW 2, and } \\
\text { reaches maximum expression } \\
\text { around PND } 35 .\end{array}$ & $\begin{array}{l}\text { OCTn2 showed 10-fold lower } \\
\text { expression compared with adult } \\
\text { levels at gestational day 13-18. } \\
\text { Most pronounced upregulation } \\
\text { present in PNW 1, which was } \\
\text { somewhat increased at PNW } 4 \text {. }\end{array}$ & $\begin{array}{l}\text { Slitt et al., 2002; Alnouti et al., 2006; } \\
\text { Sweet et al., 2006; Sweeney et al., } \\
2011\end{array}$ \\
\hline URAT1 & $\begin{array}{l}\text { URAT1 expression in infants and } \\
\text { children is higher than in term } \\
\text { newborns, adolescents, and } \\
\text { adults. URAT1 protein } \\
\text { abundance was lower in term } \\
\text { newborn and infants and } \\
\text { reached adult levels at child } \\
\text { stage. }\end{array}$ & $\begin{array}{l}\text { URAT1 showed low expression } \\
\text { at PND 2, which was greatly } \\
\text { increased from PNW } 2 \text { onward. }\end{array}$ & $\begin{array}{l}\text { URAT1 main increase in } \\
\text { expression was at PNW } 1 \text { and } 4 .\end{array}$ & $\begin{array}{l}\text { Cheng and Klaassen, 2009; Sweeney } \\
\text { et al., } 2011\end{array}$ \\
\hline PEPT2 & No fetal-adult relation described. & $\begin{array}{l}\text { Pept } 2 \text { was expressed at PND } 2 \\
\text { and was greatly increased at } \\
\text { PNW } 2 \text {. }\end{array}$ & $\begin{array}{l}\text { Pept } 2 \text { was increased at gestational } \\
\text { day } 18 \text { and at PNW } 4 .\end{array}$ & Sweeney et al., 2011 \\
\hline MATE1 & $\begin{array}{l}\text { MATE1 shows similar expression } \\
\text { and protein abundance from } \\
\text { premature up to adults. }\end{array}$ & $\begin{array}{l}\text { MATE1 was present during PND } \\
2 \text { but was greatly increased } \\
\text { from birth up to PNW } 4 .\end{array}$ & $\begin{array}{l}\text { MATE1 was increase steadily } \\
\text { throughout gestational day } \\
17-22 \text { and increased more at } \\
\text { PNW 4. MATE1 was even } \\
\text { increased more at a later age of } 6 \\
\text { mo. }\end{array}$ & $\begin{array}{l}\text { Lickteig et al., 2008; Sweeney et al., } \\
\text { 2011; Xu et al., 2017; Cheung et al., } \\
2019\end{array}$ \\
\hline NPT & No fetal-adult relation described. & $\begin{array}{l}\text { NPT1, 2a, and 2c were expressed } \\
\text { at PND 2. Upregulation of the } \\
\text { mRNA appears to start at } \\
\text { postnatal PNW } 2 .\end{array}$ & No fetal-adult relation described. & Cheng and Klaassen, 2009 \\
\hline ENT & No fetal-adult relation described. & $\begin{array}{l}\text { ENT2 was expressed in a low } \\
\text { amount at PND }-2 \text { and was } \\
\text { decreased slightly in the first } \\
\text { two PNW and is further } \\
\text { reduced at PNW } 7 \text {. }\end{array}$ & No fetal-adult relation described. & Cheng and Klaassen, 2009 \\
\hline
\end{tabular}

between PND 11 and 26 (de Zwart et al., 2008; Sweeney et al., 2011; Xu et al., 2017). Peak Pgp expression in mice kidney has been noted at PND 20/21 but decreases sharply in males at PND 45 (Pinto et al., 2005; Cui et al., 2009).

Organic anion transporters are members of the SLC family and are involved in the movement of drugs, metabolites, and toxins across the basolateral and apical membranes of the renal tubules, contributing to the secretion of a number of therapeutic agents and endogenous substrates (Burckhardt and Burckhardt, 2003). In rats and mice, renal OAT expression is low during gestation but increases substantially during the postnatal period (Buist et al., 2002; Buist and Klaassen, 2004). The expression of OAT1 and OAT3 (which are critical carriers on the basolateral border) is significant enough for detection by approximately day 16 to 17 of gestation in rodents but rises considerably between birth and PNW 3 to reach adult levels by PNW 4 (Sweeney et al., 2011). The formation of new nephrons and extensive growth of established nephrons may contribute to the high upregulation levels of transporters in the postnatal kidney in some species. Protein levels of both transporters at PNW 3 largely resemble those of adults in both mice and rats (Nakajima et al., 2000; Hwang et al., 2010). However, using PAH secretion as a surrogate for OAT1 functional maturity, PAH clearance failed to reach maximal levels in rats until 8-10 weeks of age, suggesting either that OAT transporters are not fully mature at PND 21-28 or other renal factors may be confounding the data (Sweeney et al., 2011). The latter finding illustrates that expression at the RNA level does not necessarily equate with functional capacity, which makes interpretation of the scarce data even more challenging.

Many SLC carriers are present in early renal development, including multidrug and toxin extrusion 1 (MATE) 1, organic cation transporter (OCT) 1, OCT2, OCTn1, OCTn2, urate transporter 1 (URAT), and peptide transporter 2 (Pept). These transporters show similar expression patterns at least at the transcriptional level in rodents (Pavlova et al., 2000; Sweet et al., 2006). OCT1, OCT2, OCTn1, and OCTn2 mRNA expression in mice have been shown to approach adult levels by PNW 3, and although some of this family show gender differences in adult expression, the differences are not evident until about PND 30 (Alnouti et al., 2006). MATE1 is an efflux cation transporter on the apical membrane. At PND 2, MATE1 expression in mice was only 12\%-14\% compared with PND 45 when it reached adult levels and only $50 \%$ at PND 15 . In rats, OCT2, OATP-4C1, and MATE1 expression levels were found to be low in fetal kidneys, increased gradually following birth, and increased markedly on weaning, continuing to rise until adulthood. However, for OCT2, female expression does not increase after PNW3. Organic cation transporter 3 mRNA expression levels were low in fetal and newborn kidneys but peaked at PND 35-40 in both sexes (Slitt et al., 2002; Xu et al., 2017). In humans, postnatal OAT1-mediated renal secretion is low in neonates and young infants relative to older children and adults (Momper and Nigam, 2018; Cheung et al., 2019). Organic anion transporter 3 expression is lowest in neonates and reaches adult levels before 2 years of age, but protein expression only reaches adult levels in adolescence (Cheung et al., 


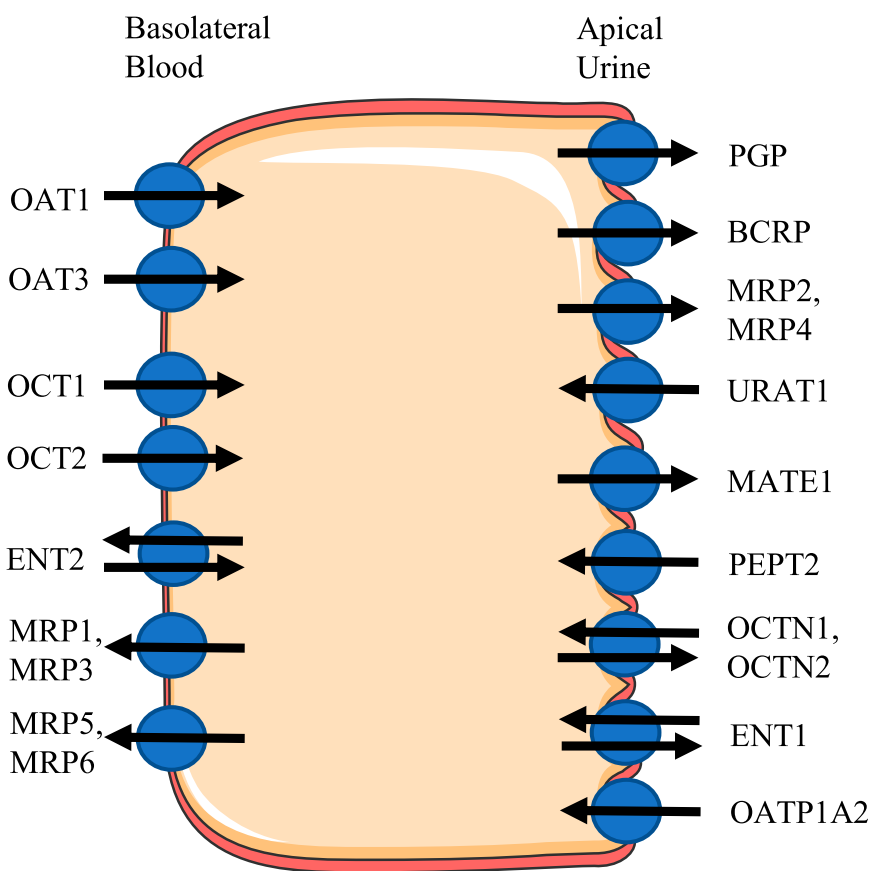

Fig. 1. Overview of transporters in the human kidney discussed in this review.

2019). Urate transporter 1 mRNA expression is highest at the infant and child stage; however, protein levels are more or less stable from childhood onward (Cheung et al., 2019). MATE1 shows similar expression and protein abundance from neonates up to adults (Cheung et al., 2019). Organic anion-transporting polypeptide B and OATP-D are both expressed in the human fetal kidney, but comparative expression has not yet been evaluated systematically throughout development (Brouwer et al., 2015).

Multidrug resistance-associated proteins (MRP) are a member of the ATP-binding cassette superfamily and include adenosine triphosphate-dependent efflux transporters, which transport a wide variety of anionic and cationic compounds across membranes in the kidney and other tissues. Of the eight mice MRPs, six MRPs (MRP1-6) are significantly expressed in the kidney. The renal ontogeny of the MRP carriers can be divided into three expression patterns in mice: 1) MRP1 expression remains relatively constant from birth to adulthood; 2) MRP2, 3, and 4 are expressed below adult levels at birth and increase during the first few weeks of age; and 3) highest expression of MRP5 is seen at birth, and expression decreases during the first few weeks of life (Maher et al., 2005). MRPs do not exhibit mature expression levels until 1 month of age or later (Maher et al., 2005, 2006a). In a publication by Konieczna et al. (2011), immunohistochemistry of human fetal kidneys demonstrated MRP1 as early as GW 5.5, which increased during gestation. Expression of MRP 2 and 4 is similar between newborns and adults (Cheung et al., 2019). Unfortunately, there are no MRP mRNA expression data to support these results in human fetuses. MRP3 and 4 are expressed at much higher levels in adult female than male kidneys and are under hormonal influence in mice, rats, and humans (Chen and Klaassen, 2004; Maher et al., 2006a).

Breast cancer resistance protein (BCRP) has been shown by immunohistochemistry at multiple stages in the human fetus within renal proximal tubules on their apical border (Konieczna et al., 2011). Breast cancer resistance protein expression level is high in newborns and reduces with age, reaching adult levels before 2 years of age. Protein abundance is similar between newborns and adults (Cheung et al., 2019).
In mice, BCRP expression is increased after gestation and increases until maturity (de Zwart et al., 2008; Sweeney et al., 2011).

There are several other transporters of note in the kidney, such as the sodium-phosphate cotransporters (NPT1, NPT2a, NPT2b, and NPT2c) and the nucleoside transporters [equilibrative nucleoside transporter (ENT) 1, ENT2, and ENT3], but ontological data in any species for these groups are rather limited. Except for ENT2, all are minimally expressed in mouse kidneys until PND 15 and then increase until maturity (Cheng and Klaassen, 2009). ENT2 is highly expressed in mice during gestation and decreases from birth until PND 15, when it is maintained until adulthood (Cheng and Klaassen, 2009).

It should be noted that there are important mechanisms of regulation of transporters, including the hepatocyte nuclear factors and the pregnane $\mathrm{X}$ receptor (PXR), during renal development. Hepatocyte nuclear factors $1 \mathrm{a}$ and $4 \mathrm{a}$ regulate the expression of many or most $(21 / 32$ tested in one study) proximal tubule transporters in ontogeny during intrauterine and later development (Maher et al., 2006b; Martovetsky et al., 2013). Though PXR regulatory factor has a larger role in the maturation of enzymes related to metabolism, PXR also regulates some transporter genes during kidney development (Tolson and Wang, 2010).

Maturation of passive tubular reabsorption was assessed in conventional pigs by Friis (1983) using sulphachlorpyridazine (SCP). Although excretion of SCP comprises both secretion as well as reabsorption, an age-dependent increase in SCP/GFR clearance ratio was observed, implicating a relative decrease in reabsorption with age.

\section{Metabolic Enzyme Maturation}

Overall, there is very little information on the ontogeny of metabolism in the kidney. Although ontogeny data in the liver has improved over the last decade after earlier gap analysis (de Wildt et al., 1999; Alcorn and McNamara, 2002), data on maturation in the kidney are still lacking. Data from liver studies demonstrated that levels of Uridine 5'diphospho-glucuronosyltransferases (UGTs) are generally lower in neonates, but maturation depends on the isoform and possibly also on the tissue examined (Ekström et al., 2013). Unfortunately, most studies failed to include both fetal and adult kidney tissues in their experiments. Interpretation of results from human studies is difficult. Although studies have been performed with known substrates for specific metabolism pathways, it is not possible to discern liver- from kidney-related effects, as there is a large overlap between enzymes in both tissues. Moreover, because of the many different techniques used, a comparison between studies is not always easy to make. The kidney plays a less prominent role in drug metabolism for most drugs compared with the liver, whereby only a small portion of the known metabolizing families are present.

Cytochrome P450 Family. In human kidney, there is evidence for the expression of various cytochrome P450 (P450) enzymes, such as CYP2B6, CYP3A5, and the CYP4 family, whereas presence of CYP2C8, CYP2C9, and CYP3A4 is considered equivocal (Knights et al., 2013) (Table 4). Though some of these enzymes are also present in animals, it may be one of the other isoforms that has a similar function. A thorough overview of P450 isoforms between species was published by Martignoni et al. (2006).

The CYP2B6 enzyme is known for the metabolism of a wide range of drug classes, including chemotherapeutics, anti-inflammatories, antiretrovirals, anesthetics, and benzodiazepines (Wang and Tompkins, 2008). Additionally, it metabolizes several insecticides and herbicides (Hodgson and Rose, 2007). Data on ontogeny and maturation in the kidney is, however, lacking in most species. Sparse data in mice showed CYP2B9 protein concentrations to be present between PNW 3 and 10. Between PNW 10 and 10 months of age, the concentrations declined in 


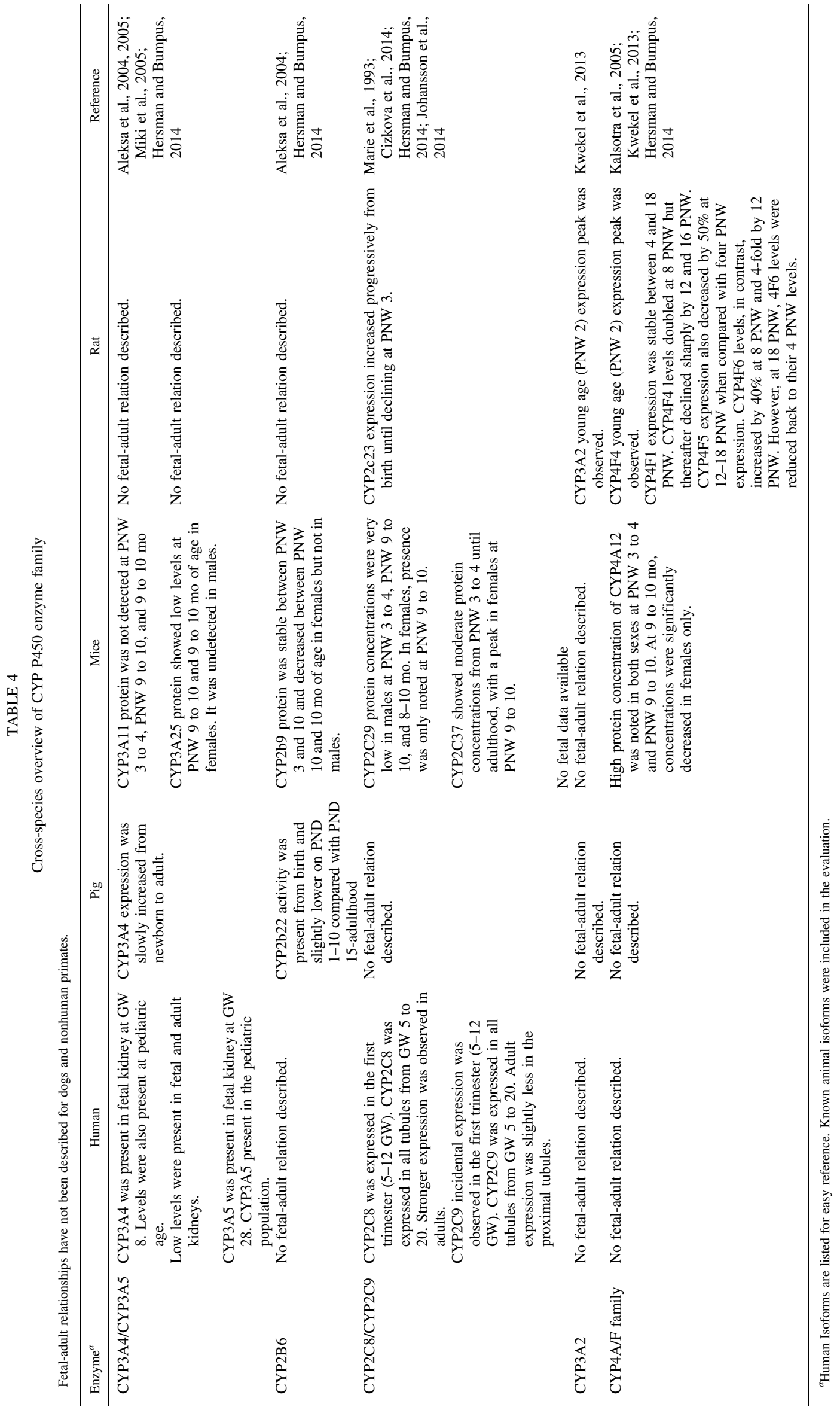

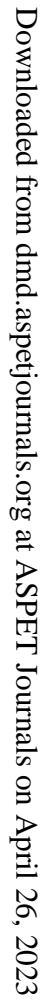


females but not in males using a proteomics approach (Hersman and Bumpus, 2014). In pigs, CYP2B22 activity was present from birth and increased from PND10-15, at which point it remains stable into adulthood (Aleksa et al., 2004).

The CYP3A4/5 enzyme is known to metabolize a wide range of drugs, including calcium channel blockers, HIV protease inhibitors, statins, and benzodiazepines. The CYP3A4/5 enzymes are slightly higher expressed in the cortex compared with the medulla (Schuetz et al., 1992) and are detected in the human fetal kidney at GW 28 and onward (Aleksa et al., 2005; Miki et al., 2005). With respect to the ontogeny and maturation of this enzyme in the kidney, not much is known in humans and other species. The CYP3A4 enzyme was shown to slowly increase in expression with age in pigs (Aleksa et al., 2004). In mice, protein concentrations of the predominant isoform CYP3A11 were undetected in kidney at PNW 3 to 4, PNW 9 to 10 , and 9 to 10 months of age. The CYP3A25 enzyme showed low levels at PNW 9 to 10 and 9 to 10 months of age in females. It was undetected in males (Hersman and Bumpus, 2014).

Several members of the CYP4 family have been identified in the kidney, including CYP4A11, CYP4F2, CYP4F8, CYP4F11, and CYP4F12. These enzymes are known to metabolize arachidonic, docosahexaenoic, and eicosapentenoic acids but are not directly related to a drug class. Data on the ontogeny/maturation of the renal CYP4 family is lacking in most species, including humans. The CYP4F4 enzyme expression was analyzed in rats and showed a peak at 2 weeks of age (Kwekel et al., 2013). The CYP4F4 enzyme levels doubled at PNW 8 but, thereafter, declined sharply by PNW 12 and PNW 16. The CYP4F5 enzyme expression also decreased by 50\% at PNW 12-18 when compared with the PNW 4 expression. The CYP4F6 enzyme levels, in contrast, increased by $40 \%$ at PNW 8 and 4-fold by PNW 12. However, at $18 \mathrm{PNW}, \mathrm{CYP} 4 \mathrm{F6}$ levels were reduced to their 4-week levels (Kalsotra et al., 2005). In mice, high protein concentrations of CYP4A12 were noted in both sexes at PNW 3 to 4 and 9 to 10 . At 9 to 10 months, concentrations were significantly decreased in females only (Hersman and Bumpus, 2014).

The CYP2C8 enzyme is known to metabolize the following substrates: amodiaquine, chloroquine, paclitaxel, repaglinide, and rosiglitazone. In humans, this gene is expressed in the first trimester and more predominant in the proximal tubule compared with the distal tubules (Cizkova et al., 2014; Johansson et al., 2014). Expression is rather stable between 5 and 20 weeks of intrauterine development. In adults, expression of this gene is slightly higher in both proximal as well as distal tubules.

The CYP2C9 known substrates are losartan, nonsteroidal antiinflammatory drugs, oral hypoglycemics, and S-warfarin. In humans, the CYP2C9 gene is expressed in the first trimester (GW 5-12) (Johansson et al., 2014). Moreover, Cizkova et al. (2014) showed expression in both proximal and distal tubules between GW 5 and GW 20. Expression was slightly less in the proximal tubule of adults compared with in utero development, and in distal tubules, expression was more-or-less similar (Cizkova et al., 2014). Limited data were available on the ontogeny of CYP2C8 and CYP2C9 isoforms in rodent species. The CYP2C23 enzyme expression was noted to increase progressively from birth until declining at PNW3 in the rat (Marie et al., 1993). In mice, data were available on CYP2C29 and CYP2C37. The CYP2C29 protein concentrations were very low in males at PNW 3 to 4 , PNW 9 to 10 , and 9 to 10 months of age. In females, protein concentrations could only be detected at PNW 9 to 10 . The CYP2C37 enzyme showed moderate protein concentrations from PNW 3 to 4 up until adulthood, with a peak in females at PNW 9 to 10 (Hersman and Bumpus, 2014).

Just as there is coregulation for transporters, the function of enzymes is also dependent on other factors. In the case of the P450 systems, P450 oxidoreductase is required for function. The importance of this enzyme is apparent because of observed embryonic lethality in knockout mice around day 8 to 9 (Shen et al., 2002; Henderson et al., 2003). Postnatal deletion is, however, viable and demonstrated in a conditional knockout model (Wu et al., 2003). Although this model has been extensively used to study effects on P450 reactions, ontogeny of this enzyme in the kidney has not been studied.

Other Metabolism Families. The major other route of metabolism in adults involves the UGT catalyzed conjugation reactions (Table 5). Many of them are present in human, but few have been described regarding ontogeny or maturation in the kidney. Exceptions are UGT1A1, which was detected in both the mesonephros and metanephros stages (Hume et al., 1995), and UGT2B7, which was more abundant in the fetal kidney compared with the liver ((Ekström et al., 2013)Ekstrom et al., 2013). In other species, no fetal-adult relations have been described. Recently, pharmacokinetic modelers hypothesized that the rate-limiting step in human neonatal liver metabolism may not be the UGT enzymes themselves but the availability of uridine 5'-diphosphate glucuronic acid (Liu et al., 2019). Human fetal kidney concentrations (GW 17-25) of uridine 5'-diphosphate glucuronic acid are approximately 1.5-times lower compared with adult kidney concentrations and 5- and 25-fold lower compared with, respectively, fetal and adult liver concentrations (Cappiello et al., 2000).

Sulfotransferases (SULT) are present and active in the kidneys, but ontogeny or maturation data are only available for a limited number of enzymes. The SULT1A1 enzyme, one of the more prominent members of the family, was detected at PNW 15 and remained unchanged in the first 1.5 postnatal years in humans (Gilissen et al., 1994). Another member of the same family, SULT1A3, shows to be more active during the intrauterine development phase. Levels of this enzyme are higher in human fetal (GW 18-25) kidneys compared with adult kidneys (Cappiello et al., 1991; Pacifici et al., 1993). Other described sulfotransferases were SULT1C2, which was shown to be present in human fetal kidney (Her et al., 1997), and SULT2A1, which was detected in human kidneys from the second half of gestation onward and reached adult levels in the neonate (Barker et al., 1994). Sulfotransferases have also been studied in rodent species. In rats, SULT1C1 and SULT1C2 expression has been studied and shown to be very little or highly expressed in the fetal kidney, respectively (Nagata et al., 1993; Dunn and Klaassen, 1998; Xiangrong et al., 2000). The SULT1C2 enzyme could also be confirmed on the protein level (Xiangrong et al., 2000). In mice, the SULT family has been studied in the C57BL/6 strain. At an age of PNW 8, very low or absent expression of SULT1B1, SULT1E1, SULT2A1/2, SULT2B1, SULT3A1, and SULT4A1 was noted. The SULT1C1 and SULT1D1 enzymes, however, increased over time from 2 days before birth to PND 45. The SULT1C2 enzyme increased in expression from 2 days before birth up until birth and remained stable up to PND 10. Thereafter, SULT1C2 expression further increased. Interestingly, expression levels started to decline in males, but not in females, at PND 22 (Alnouti and Klaassen, 2006).

Sulfotransferases can only function if there is enough 3 '-phosphoadenosine-5'-phosphosulfate (PAPS) available to donate the sulfonate group. PAPS is formed from dietary inorganic phosphate and adenosine triphosphate in a cascade of reactions catalyzed by the protein PAPSs. The isozyme PAPSs1 is stably expressed in kidneys of mice from birth until PND 15, after which it somewhat decreases (Alnouti and Klaassen, 2006). In adult rat, mouse, and dog, PAPS concentration in the kidney is rather similar and approximately three- to four-times higher compared with humans (Brzeznicka et al., 1987; Cappiello et al., 1989; Klaassen and Boles, 1997). Fetal kidney concentrations of PAPS in common laboratory species have not been reported.

The glutathione S-transferase (GST) family consist of nine subclasses, whereby the $\alpha$, the $\mu$, and the $\pi$ classes have been mostly described in 
TABLE 5

Cross-species overview of other metabolizing enzyme families

Fetal-adult relationships have not been described for nonhuman primates, dogs, and pigs.

\begin{tabular}{|c|c|c|c|c|}
\hline Enzyme & Human & Mice & Rat & Reference \\
\hline $\begin{array}{l}\text { UGT } \\
\text { family }\end{array}$ & $\begin{array}{l}\text { UGT1A1 was detected in mesonephros/ } \\
\text { metanephros stage. } \\
\text { UGT2B7 was more abundant in fetal } \\
\text { kidney than liver. }\end{array}$ & No fetal-adult relation described. & $\begin{array}{l}\text { No fetal-adult relation } \\
\text { described. }\end{array}$ & $\begin{array}{l}\text { Lucier et al., 1977; Hume et al., 1995; } \\
\quad \text { (Ekström et al., 2013) }\end{array}$ \\
\hline \multirow[t]{4}{*}{$\begin{array}{l}\text { SULT } \\
\text { family }\end{array}$} & $\begin{array}{l}\text { SULT1A3 levels were higher in fetal } \\
(18-25 \mathrm{GW}) \text { kidneys than in adults. }\end{array}$ & $\begin{array}{l}\text { SULT 1b1, SULT1e1, SULT2a1/2, } \\
\text { SULT2b1, SULT3A1, SULT4a1 } \\
\text { levels were very low or absent ( } 8 \\
\text { PNW). }\end{array}$ & $\begin{array}{l}\text { SULT1C1 mRNA expression } \\
\text { was mainly in liver, with } \\
\text { very low or no expression in } \\
\text { kidney, spleen, lung, colon, } \\
\text { intestine, or brain. }\end{array}$ & \multirow[t]{4}{*}{$\begin{array}{l}\text { Cappiello et al., 1991; Nagata et al., } \\
\text { 1993; Pacifici et al., 1993; Barker } \\
\text { et al., 1994; Gilissen et al., 1994; } \\
\text { Her et al., 1997; Dunn and } \\
\text { Klaassen, 1998; Xiangrong et al., } \\
\text { 2000; Alnouti and Klaassen, } 2006\end{array}$} \\
\hline & $\begin{array}{l}\text { SULT1A1 was detected at } 15 \text { PNW and } \\
\text { remained unchanged in the first } 1.5 \\
\text { postnatal yr. }\end{array}$ & $\begin{array}{l}\text { SULT1C1 and SULT1D1 increased } \\
\text { over time from PND } 2 \text { to PND } 45 \text {. }\end{array}$ & $\begin{array}{l}\text { SULT1C } 2 \text { mRNA and protein } \\
\text { are highly expressed in } \\
\text { kidney, followed by stomach } \\
\text { and liver. }\end{array}$ & \\
\hline & $\begin{array}{l}\text { SULT2A1 was low to nondetectable } \\
\text { before } 25 \text { GW but was then increased } \\
\text { substantially during the latter half of } \\
\text { gestation to approach adult levels } \\
\text { during neonate. }\end{array}$ & $\begin{array}{l}\text { PAPSs1 remained equal over this time } \\
\text { period. }\end{array}$ & & \\
\hline & SULT1C2 was detected in fetal kidneys. & $\begin{array}{l}\text { Renal SULT1C2 mRNA was } \\
\text { expressed at high levels in fetuses } \\
2 \text { days before birth and remained } \\
\text { constant after birth until 10 PND, } \\
\text { when mRNA levels began to } \\
\text { increase. However, } 22 \text { PND, mRNA } \\
\text { levels began to decline in male } \\
\text { kidneys, whereas female levels } \\
\text { remained constant. }\end{array}$ & & \\
\hline $\begin{array}{l}\text { GSTA1/ } \\
\text { A2 }\end{array}$ & $\begin{array}{l}\text { GSTA1/A2 protein were detected and } \\
\text { active in the kidney from } 8 \mathrm{GW} \text { and } \\
\text { increased in function in the first } 2 \text { life- } \\
\text { years }\end{array}$ & No fetal-adult relation described. & $\begin{array}{l}\text { GSTA1 was increased from } \\
\text { PNW } 1 \text { to } 4 \text {. GSTA2 was } \\
\text { only detected from PNW } \\
\text { k3-4 }\end{array}$ & $\begin{array}{l}\text { Hiley et al., 1989; Beckett et al., 1990; } \\
\text { Oberley et al., 1995; Raijmakers } \\
\text { et al., } 2001\end{array}$ \\
\hline GSTm & $\begin{array}{l}\text { GSTm levels were constant pre- and } \\
\text { postnatal. } \\
\text { GSTm protein was detectable at GW } 8 \\
\text { and slightly increased at GW } 13 \text {. } \\
\text { Concentration was on average similar } \\
\text { in adult life. }\end{array}$ & No fetal-adult relation described. & $\begin{array}{l}\text { No fetal data available. } \\
\text { No fetal-adult relation } \\
\text { described. }\end{array}$ & $\begin{array}{l}\text { Beckett et al., 1990; Raijmakers et al., } \\
2001\end{array}$ \\
\hline GSTP1 & $\begin{array}{l}\text { GSTP1 activity was decreased from pre- } \\
\text { to postnatal age. GSTP1 protein was } \\
\text { detectable at GW } 8 \text { of and rapidly } \\
\text { increased at GW } 13 \text {. Concentration } \\
\text { was lower in adult life. }\end{array}$ & No fetal-adult relation described. & $\begin{array}{l}\text { GSTP showed a relatively } \\
\text { stable signal at PNW 1-4 } \\
\text { No fetal data available. }\end{array}$ & $\begin{array}{l}\text { Beckett et al., 1990; Oberley et al., } \\
\text { 1995; Raijmakers et al., } 2001\end{array}$ \\
\hline EPHX & $\begin{array}{l}\text { EPHX } 1 \text { was present and increased from } \\
7.5 \text { to and } 25 \mathrm{GW} \text {. }\end{array}$ & No fetal-adult relation described. & $\begin{array}{l}\text { No fetal-adult relation } \\
\text { described. }\end{array}$ & $\begin{array}{l}\text { Pacifici et al., 1983; Omiecinski et al., } \\
1994\end{array}$ \\
\hline NATS & $\begin{array}{l}\text { NATS was present in fetuses, and } \\
\text { activity was somewhat comparable } \\
\text { between fetal and adult tissue. }\end{array}$ & No fetal-adult relation described. & $\begin{array}{l}\text { No fetal-adult relation } \\
\text { described. }\end{array}$ & Pacifici et al., 1986 \\
\hline
\end{tabular}

EPHX, epoxide hydrolase; NATS, N-acetyltransferase.

the kidney. Human data showed GST $\alpha$ protein to be detectable in kidneys from GW 8 onward, with increasing function in the first 2 lifeyears (Hiley et al., 1989; Beckett et al., 1990; Raijmakers et al., 2001). The GST $\mu$ enzyme was also detectable on a protein level from GW 8 and slightly increased in GW 13. The protein levels remain fairly constant postnatally up to adulthood (Beckett et al., 1990; Raijmakers et al., 2001). The most prominent GST in the prenatal stages was GST $\pi$, which was detected at the protein level from GW 8 and was pronouncedly increased in GW 13 (Raijmakers et al., 2001). After birth, levels declined and remained lower during adulthood (Beckett et al., 1990; Raijmakers et al., 2001). All three GST family members were also confirmed to show enzyme activity from GW 8, indicating these are all fully functional during the prenatal stages. In other species, only limited data on GST ontogeny are available. In rat, GST $\alpha$ was noted to increase between PNW 1 and PNW 4, and GST $\pi$ showed a relatively stable signal between PNW 1 and 4 (Oberley et al., 1995).
Other minor metabolism pathways, such as epoxide hydrolases, $\mathrm{N}$-acetyltransferases, methyltransferases, and amino acid conjugates have been very poorly described in the kidney. Human data showed epoxide hydrolases to be present and increasing in the kidney from 7.5 to $25 \mathrm{GW}$ (Pacifici et al., 1983; Omiecinski et al., 1994), and $\mathrm{N}$-acetyltransferases were shown to be present in the kidney at a level somewhat comparable with adult kidney tissue (Pacifici et al., 1986). Data on expression in the kidney of other species is currently lacking.

Renal Excretion Maturation. Renal excretion of drugs is the net result of three main processes: 1) GFR, 2) tubular secretion, and 3) tubular reabsorption. Maturation of the kidney function has an impact on the renal excretion of drugs on the one hand but might also affect absorption, distribution, metabolism, and nonrenal clearance of drugs on the other hand. Especially during the first 2 years of life, changes in kidney function can alter drug exposure and drug response, potentially leading to a shift in efficacy/safety balance (Rodieux et al., 2015). 
Immaturity of the kidney function results in alteration of plasma clearance and prolongation of elimination half-life of renally cleared drugs, necessitating adaptations of the dose and/or the dosing interval (Kearns et al., 2003). During the human neonatal period, renal excretion of drugs is decreased because of immature GFR and tubular secretion, whereas similar or even greater excretion was observed for many drugs during late infancy and/or childhood. The latter necessitates higher doses on a per-kilogram basis in infants and in children to reach sufficient plasma concentration levels (i.e., dose per kilogram of digoxin is much higher in infants than in adults) (Fernandez et al., 2011).

Renal drug excretion represents unbound (= "free") drugs that will be filtered across the glomerular membrane into the renal tubules. Alterations in plasma/tissue protein binding will be reflected in lower or higher concentrations of unbound drugs. An increase in unbound drug concentration will lead to an increase in renal clearance, as there is more available for glomerular filtration and/or tubular secretion. Even though plasma/tissue protein binding is a major determinant of drug disposition, the clinical implication of altered plasma/tissue protein binding is rather limited but can sometimes require dosage adaptations (Grandison and Boudinot, 2000).

Knowledge of which renal drug transporters (i.e., OCT and OATP) are involved in renal drug clearance and their impact on renal excretion in the pediatric population needs to be taken into account when considering whether pediatric-adapted dosing regimens are required ('t Jong, 2014). Moreover, as suggested by Rodieux et al. (2015), it is important to map the polymorphisms of genes encoding for drugmetabolizing enzymes, drug transporters, and drug targets (pharmacogenomics), as it might influence drug disposition and thereby alter the efficacy/safety balance. As stated above, detailed knowledge on transporter and metabolism maturation is still lacking, urging the need for additional research.

Over the years, allometric scaling equations have been used to predict the size-related changes in clearance between species on the one hand and within species (i.e., in humans: adults to children) on the other hand. In neonates and infants, simple allometric methods based on body size alone do not suffice because body size is not representative for overall organ function throughout the pediatric population (Mahmood, 2014). Therefore, incorporation of the role of maturation and growth of, i.e., the kidney in allometric models should be applied. The latter is confirmed by Peeters et al. (2010), who used allometric models developed in rats, children, and adults to predict the propofol clearance in children. The authors concluded that these models, based on body weight, could be used to predict the propofol clearance in children older than 2 years, but additional maturational functions should be incorporated to be able to correctly predict the clearance in younger children. Mahmood and Tegenge (2019) compared the predictive capacity of physiologically based PK modeling and allometric scaling (age-dependent exponent model) for 73 drugs to predict drug clearance in the pediatric population (neonates to adolescents). The predictive power to predict drug clearance was equal for both methods. The simplicity of allometric scaling in comparison with PBPK modeling favors allometry to estimate pediatric drug clearance and consequently to perform first-in-pediatric dose estimations.

\section{Conclusion}

The paradigm that children should not be regarded as small adults in terms of drug handling, nor should neonates be regarded as small children, is now generally accepted. Unfortunately, our knowledge of kidney ADME ontogeny is still sparse in some areas. The major kidney function characteristics such as GFR, RBF, and concentrating ability are generally well understood; however, detailed knowledge on transporter and metabolism maturation is still lacking. Preclinical data in those areas is mostly restricted to rat and mouse only and generally only covers the expression levels of transporter or enzyme-encoding genes. Such expression levels do not necessarily need to correspond with actual protein abundance and function as we learned from human data. It is the interaction between all these characteristics that is responsible for the majority of pronounced differences in toxicity of pharmaceutical agents noted between neonates and older children and between pediatric and adult patients. Of additional note, the developing kidney is prenatally as well as postnatally sensitive or vulnerable to morphologic and functional disturbances during its different phases of growth and differentiation. Drug administration can result in both morphologic and functional renal changes, depending on the timing, level, and duration of the exposure. Primarily, more knowledge on a functional level is needed to predict the kinetics and toxicity in neonate/juvenile toxicity or efficacy studies and improve the risk assessment to the human population. Nevertheless, there are a wide variety of species that can be used in preclinical embryofetal and juvenile toxicity studies focusing on renal development that can be extrapolated to human kidney development.

\section{Authorship Contributions}

Participated in research design: Bueters, Bael, Gasthuys, Chen, Schreuder, Frazier.

Performed data analysis: Bueters, Bael, Gasthuys, Schreuder, Frazier.

Wrote or contributed to the writing of the manuscrupt: Bueters, Bael, Gasthuys, Chen, Schreuder, Frazier.

\section{References}

Abramovich DR(1968) The volume of amniotic fluid in early pregnancy. J Obstet Gynaecol Br Commonw 75:728-731.

Ahmadimoghaddam D, Zemankova L, Nachtigal P, Dolezelova E, Neumanova Z, Cerveny L, Ceckova M, Kacerovský M, Micuda S, and Staud F(2013) Organic cation transporter 3 (OCT3/ SLC22A3) and multidrug and toxin extrusion 1 (MATE1/SLC47A1) transporter in the placenta and fetal tissues: expression profile and fetus protective role at different stages of gestation. Biol Reprod 88:55.

Alcorn J and McNamara PJ(2002) Ontogeny of hepatic and renal systemic clearance pathways in infants: part I. Clin Pharmacokinet 41:959-998.

Aleksa K, Halachmi N, Ito S, and Koren G(2004) Renal ontogeny of ifosfamide nephrotoxicity. J Lab Clin Med 144:285-293.

Aleksa K, Matsell D, Krausz K, Gelboin H, Ito S, and Koren G(2005) Cytochrome P450 3A and 2B6 in the developing kidney: implications for ifosfamide nephrotoxicity. Pediatr Nephrol 20 : $872-885$.

Alnouti $\mathrm{Y}$ and Klaassen CD(2006) Tissue distribution and ontogeny of sulfotransferase enzymes in mice. Toxicol Sci 93:242-255.

Alnouti Y, Petrick JS, and Klaassen CD(2006) Tissue distribution and ontogeny of organic cation transporters in mice. Drug Metab Dispos 34:477-482.

Artz NS, Wentland AL, Sadowski EA, Djamali A, Grist TM, Seo S, and Fain SB(2011) Comparing kidney perfusion using noncontrast arterial spin labeling MRI and microsphere methods in an interventional swine model. Invest Radiol 46:124-131.

Aschinberg LC, Goldsmith DI, Olbing H, Spitzer A, Edelmann CM Jr., and Blaufox MD(1975) Neonatal changes in renal blood flow distribution in puppies. Am J Physiol 228:1453-1461.

Baer PG and Navar LG(1973) Renal vasodilation and uncoupling of blood flow and filtration rate autoregulation. Kidney Int 4:12-21.

Barker EV, Hume R, Hallas A, and Coughtrie WH(1994) Dehydroepiandrosterone sulfotransferase in the developing human fetus: quantitative biochemical and immunological characterization of the hepatic, renal, and adrenal enzymes. Endocrinology 134:982-989.

Barnett C, Nnoli O, Abdulmahdi W, Nesi L, Shen M, Zullo JA, Payne DL, Azar T, Dwivedi P, Syed K, et al.(2017) Low birth weight is associated with impaired murine kidney development and function. Pediatr Res 82:340-348.

Baum M(2016) Neonatal nephrology. Curr Opin Pediatr 28:170-172.

Beckett GJ, Howie AF, Hume R, Matharoo B, Hiley C, Jones P, and Strange RC(1990) Human glutathione S-transferases: radioimmunoassay studies on the expression of alpha-, mu- and piclass isoenzymes in developing lung and kidney. Biochim Biophys Acta 1036:176-182.

Behrman RE and Lees MH(1971) Organ blood flows of the fetal, newborn and adult rhesus monkey: a comparative study. Biol Neonate 18:330-340.

Brouwer KL, Aleksunes LM, Brandys B, Giacoia GP, Knipp G, Lukacova V, Meibohm B, Nigam SK, Rieder M, and de Wildt SN; Pediatric Transporter Working Group (2015) Human ontogeny of drug transporters: review and recommendations of the Pediatric Transporter Working Group. Clin Pharmacol Ther 98:266-287.

Brzeznicka EA, Hazelton GA, and Klaassen CD(1987) Comparison of adenosine 3'-phosphate 5'phosphosulfate concentrations in tissues from different laboratory animals. Drug Metab Dispos 15:133-135.

Buist SC, Cherrington NJ, Choudhuri S, Hartley DP, and Klaassen CD(2002) Gender-specific and developmental influences on the expression of rat organic anion transporters. J Pharmacol Exp Ther 301:145-151.

Buist SC and Klaassen CD(2004) Rat and mouse differences in gender-predominant expression of organic anion transporter (Oat1-3; Slc22a6-8) mRNA levels. Drug Metab Dispos 32:620-625. 
Burckhardt BC and Burckhardt G(2003) Transport of organic anions across the basolateral membrane of proximal tubule cells. Rev Physiol Biochem Pharmacol 146:95-158.

Cappiello M, Franchi M, Giuliani L, and Pacifici GM(1989) Distribution of 2-naphthol sulphotransferase and its endogenous substrate adenosine $3^{\prime}$-phosphate $5^{\prime}$-phosphosulphate in human tissues. Eur J Clin Pharmacol 37:317-320.

Cappiello M, Giuliani L, Rane A, and Pacifici GM(1991) Dopamine sulphotransferase is better developed than p-nitrophenol sulphotransferase in the human fetus. Dev Pharmacol Ther 16: 83-88.

Cappiello M, Giuliani L, Rane A, and Pacifici GM(2000) Uridine 5'-diphosphoglucuronic acid (UDPGLcUA) in the human fetal liver, kidney and placenta. Eur J Drug Metab Pharmacokine 25:161-163.

Cappon GD and Hurtt ME(2010) Developmental toxicity of the kidney. Reprod Toxicol 3 : 193-204.

Cervenka L, Mitchell KD, and Navar LG(1999) Renal function in mice: effects of volume expansion and angiotensin II. J Am Soc Nephrol 10:2631-2636.

Chen C and Klaassen CD(2004) Rat multidrug resistance protein 4 (Mrp4, Abcc4): molecular cloning, organ distribution, postnatal renal expression, and chemical inducibility. Biochem Biophys Res Commun 317:46-53.

Cheng X and Klaassen CD(2009) Tissue distribution, ontogeny, and hormonal regulation of xenobiotic transporters in mouse kidneys. Drug Metab Dispos 37:2178-2185.

Cheng X, Maher J, Chen C, and Klaassen CD(2005) Tissue distribution and ontogeny of mouse organic anion transporting polypeptides (Oatps). Drug Metab Dispos 33:1062-1073.

Cheung KWK, van Groen BD, Spaans E, van Borselen MD, de Bruijn ACJM, Simons-Oosterhuis Y, Tibboel D, Samsom JN, Verdijk RM, Smeets B, et al.(2019) A comprehensive analysis of ontogeny of renal drug transporters: mRNA analyses, quantitative proteomics, and localization. Clin Pharmacol Ther 106:1083-1092.

Chevalier RL and Norwood VF (2011) Functional development of the kidney in utero, in Fetal and Neonatal Physiology (Polin RA, Fox WW, and Abman SH eds), 4th ed, pp Section XVI 1316 , Elsevier Saunders, Philadelphia.

Chevalier RL and Thornhill BA(1995) Ureteral obstruction in the neonatal rat: renal nerves modulate hemodynamic effects. Pediatr Nephrol 9:447-450.

Cizkova K, Konieczna A, Erdosova B, and Ehrmann J(2014) Time-dependent expression of cytochrome p450 epoxygenases during human prenatal development. Organogenesis 10:53-61.

Cui YJ, Cheng X, Weaver YM, and Klaassen CD(2009) Tissue distribution, gender-divergent expression, ontogeny, and chemical induction of multidrug resistance transporter genes (Mdrla, Mdr1b, Mdr2) in mice. Drug Metab Dispos 37:203-210.

Cullen-McEwen LA, Kett MM, Dowling J, Anderson WP, and Bertram JF(2003) Nephron number, renal function, and arterial pressure in aged GDNF heterozygous mice. Hypertension 41: 335-340.

Cuzzolin L and Agostino R(2016) Off-label and unlicensed drug treatments in Neonatal Intensive Care Units: an Italian multicentre study. Eur J Clin Pharmacol 72:117-123.

De Schaepdrijver LM, Annaert PPJ, and Chen CL(2019) Ontogeny of ADME processes during postnatal development in man and preclinical species: a comprehensive review. Drug Metab Dispos 47:295.

de Wildt SN, Kearns GL, Leeder JS, and van den Anker JN(1999) Glucuronidation in humans. Pharmacogenetic and developmental aspects. Clin Pharmacokinet 36:439-452.

de Zwart L, Scholten M, Monbaliu JG, Annaert PP, Van Houdt JM, Van den Wyngaert I, De Schaepdrijver LM, Bailey GP, Coogan TP, Coussement WC, et al.(2008) The ontogeny of drug metabolizing enzymes and transporters in the rat. Reprod Toxicol 26:220-230.

Dunn RT II and Klaassen CD(1998) Tissue-specific expression of rat sulfotransferase messenger RNAs. Drug Metab Dispos 26:598-604.

Eisenbrandt DL and Phemister RD(1979) Postnatal development of the canine kidney: quantitative and qualitative morphology. Am J Anat 154:179-193.

Ekström L, Johansson M, and Rane A(2013) Tissue distribution and relative gene expression of UDP-glucuronosyltransferases (2B7, 2B15, 2B17) in the human fetus. Drug Metab Dispos 41 291-295.

Ennulat D, Ringenberg M, and Frazier KS(2018) Toxicologic Pathology Forum Opinion Paper*: recommendations for a tiered approach to nonclinical mechanistic nephrotoxicity evaluation. Toxicol Pathol 46:636-646.

Fagerquist M(2012) Renal function and urine production in the compromised fetus, From Preconception to Postpartum, IntechOpen, London.

Fernandez E, Perez R, Hernandez A, Tejada P, Arteta M, and Ramos JT(2011) Factors and mechanisms for pharmacokinetic differences between pediatric population and adults. Phar maceutics 3:53-72.

Field LJ, Veress AT, Steinhelper ME, Cochrane K, and Sonnenberg H(1991) Kidney function in ANF-transgenic mice: effect of blood volume expansion. Am J Physiol 260:R1-R5.

Finco DR, Tabaru H, Brown SA, and Barsanti JA(1993) Endogenous creatinine clearance measurement of glomerular filtration rate in dogs. Am J Vet Res 54:1575-1578.

Flemming B, Arenz N, Seeliger E, Wronski T, Steer K, and Persson PB(2001) Time-dependent autoregulation of renal blood flow in conscious rats. J Am Soc Nephrol 12:2253-2262.

Frazier KS(2017) Species differences in renal development and associated developmental nephrotoxicity. Birth Defects Res 109:1243-1256.

Frazier KS, Ryan AM, Peterson RA, and Obert LA(2019) Kidney pathology and investigative nephrotoxicology strategies across species. Semin Nephrol 39:190-201.

Frazier KS and Seely JC (2018) Urinary system, in Toxicologic Pathology: Nonclinical Safety Assessment, 2nd ednd (Sahota PS, Popp JA, Hardisty JF, Gopinath C, and Bouchard P eds) pp 569-638, CRC Press, Boca Raton, FL

Frazier KS, Seely JC, Hard GC, Betton G, Burnett R, Nakatsuji S, Nishikawa A, Durchfeld-Meyer $\mathrm{B}$, and Bube A(2012) Proliferative and nonproliferative lesions of the rat and mouse urinary system. Toxicol Pathol 40 (4 Suppl):14S-86S.

Friis C(1979) Postnatal development of renal function in piglets: glomerular filtration rate, clearance of PAH and PAH extraction. Biol Neonate 35:180-187.

Friis C(1980) Postnatal development of the pig kidney: ultrastucure of the glomerulus and the proximal tubule. J Anat 130:513-526.

Friis C(1983) Renal excretion of drugs during postnatal development in piglets. Vet Res Commun 7: 349-352.

Gans JH and Mercer PF(1984) The kidneys, in Dukes' Physiology of Domestic Animals (Dukes HH and Swenson MJ 517, Cornell University Press, Ithaca, NY.

Gasthuys E, Devreese M, Millecam J, Sys S, Vanderperren K, Delanghe J, Vande Walle J, Heyndrickx M, and Croubels S(2017) Postnatal maturation of the glomerular filtration rate in conventional growing piglets as potential juvenile animal model for preclinical pharmaceutical research. Front Pharmacol 8:431.

Gasthuys E, Vandecasteele T, De Bruyne P, Walle JV, De Backer P, Cornillie P, Devreese M, and Croubels $S(2016)$ The potential use of piglets as human pediatric surrogate for preclinical pharmacokinetic and pharmacodynamic drug testing. Curr Pharm Des 22:4069-4085.

Gilissen RA, Hume R, Meerman JH, and Coughtrie MW(1994) Sulphation of N-hydroxy-4-aminobiphenyl and N-hydroxy-4-acetylaminobiphenyl by human foetal and neonatal sulphotransferase. Biochem Pharmacol 48:837-840.

Gomez RA, Sequeira Lopez ML, Fernandez L, Cherñavvsky DR, and Norwood VF(1999) The maturing kidney: development and susceptibility. Ren Fail 21:283-291.

Grandison MK and Boudinot $\mathrm{FD}(2000)$ Age-related changes in protein binding of drugs: implications for therapy. Clin Pharmacokinet 38:271-290.

Groseclose MR, Laffan SB, Frazier KS, Hughes-Earle A, and Castellino S(2015) Imaging MS in toxicology: an investigation of juvenile rat nephrotoxicity associated with dabrafenib administration. J Am Soc Mass Spectrom 26:887-898.

Grunert D, Schöning M, and Rosendahl W(1990) Renal blood flow and flow velocity in children and adolescents: duplex Doppler evaluation. Eur J Pediatr 149:287-292.

Gruskin AB, Edelmann CM Jr., and Yuan S(1970) Maturational changes in renal blood flow in piglets. Pediatr Res 4:7-13.

Guron G(2005) Renal haemodynamics and function in weanling rats treated with enalapril from birth. Clin Exp Pharmacol Physiol 32:865-870.

Hausner EA, Elmore SA, and Yang X(2019) Overview of the components of cardiac metabolism. Drug Metab Dispos 47:673-688.

Hayton WL(2000) Maturation and growth of renal function: dosing renally cleared drugs in children. AAPS PharmSci 2.E3.

Henderson CJ, Otto DM, Carrie D, Magnuson MA, McLaren AW, Rosewell I, and Wolf CR(2003) Inactivation of the hepatic cytochrome P450 system by conditional deletion of hepatic cytochrome P450 reductase. J Biol Chem 278:13480-13486.

Her C, Kaur GP, Athwal RS, and Weinshilboum RM(1997) Human sulfotransferase SULT1C1: cDNA cloning, tissue-specific expression, and chromosomal localization. Genomics 41:467-470.

Hersman EM and Bumpus NN(2014) A targeted proteomics approach for profiling murine cytochrome P450 expression. J Pharmacol Exp Ther 349:221-228.

Hiley C, Bell J, Hume R, and Strange R(1989) Differential expression of alpha and pi isoenzymes of glutathione S-transferase in developing human kidney. Biochim Biophys Acta 990:321-324.

Hodgson E and Rose RL(2007) The importance of cytochrome P450 2B6 in the human metabolism of environmental chemicals. Pharmacol Ther 113:420-428.

Horster M(1977) Nephron function and perinatal homeostasis. Ann Rech Vet 8:468-482.

Horster M and Lewy JE(1970) Filtration fraction and extraction of PAH during neonatal period in the rat. Am J Physiol 219:1061-1065.

Hume R, Coughtrie MW, and Burchell B(1995) Differential localisation of UDPglucuronosyltransferase in kidney during human embryonic and fetal development. Arch Toxicol 69:242-247.

Hwang JS, Park EY, Kim WY, Yang CW, and Kim J(2010) Expression of OAT1 and OAT3 in differentiating proximal tubules of the mouse kidney. Histol Histopathol 25:33-44.

Iliescu R, Cazan R, McLemore GR Jr., Venegas-Pont M, and Ryan MJ(2008) Renal blood flow and dynamic autoregulation in conscious mice. Am J Physiol Renal Physiol 295:F734-F740.

Iwama R, Sato T, Sakurai K, Takasuna K, Ichijo T, Furuhama K, and Satoh H(2014) Estimation of glomerular filtration rate in cynomolgus monkeys (Macaca fascicularis). J Vet Med Sci 76: $1423-1426$.

Johansson M, Strahm E, Rane A, and Ekström L(2014) CYP2C8 and CYP2C9 mRNA expression profile in the human fetus. Front Genet 5:58.

Jose PA, Fildes RD, Gomez RA, Chevalier RL, and Robillard JE(1994) Neonatal renal function and physiology. Curr Opin Pediatr 6:172-177.

Jose PA, Slotkoff LM, Montgomery S, Calcagno PL, and Eisner G(1975) Autoregulation of renal blood flow in the puppy. Am J Physiol 229:983-988.

Just A, Wittmann U, Ehmke H, and Kirchheim HR(1998) Autoregulation of renal blood flow in the conscious dog and the contribution of the tubuloglomerular feedback. $J$ Physiol 506:275-290.

Kalsotra A, Cui X, Anakk S, Hinojos CA, Doris PA, and Strobel HW(2005) Renal localization, expression, and developmental regulation of $\mathrm{P} 4504 \mathrm{~F}$ cytochromes in three substrains of spontaneously hypertensive rats. Biochem Biophys Res Commun 338:423-431.

Kaskel FJ and Kleinman LI(1976) Effect of diet on renal response to salt challenge in neonatal piglets. Biol Neonate 29:306-314.

Kearns GL, Abdel-Rahman SM, Alander SW, Blowey DL, Leeder JS, and Kauffman RE(2003) Developmental pharmacology--drug disposition, action, and therapy in infants and children. $N$ Engl J Med 349:1157-1167.

Klaassen CD and Boles JW(1997) Sulfation and sulfotransferases 5: the importance of 3' phosphoadenosine 5 '-phosphosulfate (PAPS) in the regulation of sulfation. FASEB $J$ 11: 404-418.

Kleinman LI(1982) Developmental renal physiology. Physiologist 25:104-110.

Kleinman LI and Lubbe RJ(1972) Factors affecting the maturation of glomerular filtration rate and renal plasma flow in the new-born dog. $J$ Physiol 223:395-409.

Knights KM, Rowland A, and Miners JO(2013) Renal drug metabolism in humans: the potential for drug-endobiotic interactions involving cytochrome P450 (CYP) and UDPglucuronosyltransferase (UGT). Br J Clin Pharmacol 76:587-602.

Konieczna A, Erdösová B, Lichnovská R, Jandl M, Cížková K, and Ehrmann J(2011) Differential expression of ABC transporters (MDR1, MRP1, BCRP) in developing human embryos. $J$ Mol Histol 42:567-574

Kwekel JC, Desai VG, Moland CL, Vijay V, and Fuscoe JC(2013) Life cycle analysis of kidney gene expression in male F344 rats. PLoS One 8:e75305.

Laughon MM, Avant D, Tripathi N, Hornik CP, Cohen-Wolkowiez M, Clark RH, Smith PB, and Rodriguez W(2014) Drug labeling and exposure in neonates. JAMA Pediatr 168:130-136. Lickteig AJ, Cheng X, Augustine LM, Klaassen CD, and Cherrington NJ(2008) Tissue distribution, ontogeny and induction of the transporters Multidrug and toxin extrusion (MATE) 1 and MATE2 mRNA expression levels in mice. Life Sci 83:59-64.

Liu T, Lewis TR, Moore JN, Kraft WK, Gauda EB, Sartori D, Moody DE, Gobburu JVS, and Ivaturi V(2019) Could postnatal age-related uridine diphosphate glucuronic acid be a ratelimiting factor in the metabolism of morphine during the first week of life? CPT Pharmacometrics Syst Pharmacol 8:469-477.

Liu YP, Song R, Liang C, Chen X, and Liu B(2012) Arterial spin labeling blood flow magnetic resonance imaging for evaluation of renal injury. Am J Physiol Renal Physiol 303:F551-F558. 
Lopez-Nieto CE, You G, Bush KT, Barros EJ, Beier DR, and Nigam SK(1997) Molecular cloning and characterization of NKT, a gene product related to the organic cation transporter family that is almost exclusively expressed in the kidney. J Biol Chem 272: 6471-6478.

Lucier GW, Sonawane BR, and McDaniel OS(1977) Glucuronidation and deglucuronidation reactions in hepatic and extrahepatic tissues during perinatal development. Drug Metab Dispos 5 : 279-287.

Lumbers ER(1995) Functions of the renin-angiotensin system during development. Clin Exp Pharmacol Physiol 22:499-505.

Maher JM, Cheng X, Tanaka Y, Scheffer GL, and Klaassen CD(2006a) Hormonal regulation of renal multidrug resistance-associated proteins 3 and 4 (Mrp3 and Mrp4) in mice. Biochem Pharmacol 71:1470-1478.

Maher JM, Slitt AL, Callaghan TN, Cheng X, Cheung C, Gonzalez FJ, and Klaassen CD(2006b) Alterations in transporter expression in liver, kidney, and duodenum after targeted disruption of the transcription factor HNF1alpha. Biochem Pharmacol 72:512-522.

Maher JM, Slitt AL, Cherrington NJ, Cheng X, and Klaassen CD(2005) Tissue distribution and hepatic and renal ontogeny of the multidrug resistance-associated protein (Mrp) family in mice. Drug Metab Dispos 33:947-955.

Mahmood I(2014) Dosing in children: a critical review of the pharmacokinetic allometric scaling and modelling approaches in paediatric drug development and clinical settings. Clin Pharmacokinet 53:327-346.

Mahmood I and Tegenge MA(2019) A comparative study between allometric scaling and physiologically based pharmacokinetic modeling for the prediction of drug clearance from neonates to adolescents. J Clin Pharmacol 59:189-197.

Marcel de Vries PA, Navis G, de Boer E, de Jong PE, and de Zeeuw D(1997) A method for accurate measurement of GFR in conscious, spontaneously voiding rats. Kidney Int 52:244-247.

Marie S, Roussel F, and Cresteil T(1993) Age- and tissue-dependent expression of CYP2C23 in the rat. Biochim Biophys Acta 1172:124-130.

Martignoni M, Groothuis GM, and de Kanter R(2006) Species differences between mouse, rat, dog, monkey and human CYP-mediated drug metabolism, inhibition and induction. Expert Opin Drug Metab Toxicol 2:875-894.

Martovetsky G, Tee JB, and Nigam SK(2013) Hepatocyte nuclear factors $4 \alpha$ and $1 \alpha$ regulate kidney developmental expression of drug-metabolizing enzymes and drug transporters. Mol Pharmacol 84:808-823.

McMahon AP(2016) Development of the mammalian kidney. Curr Top Dev Biol 117:31-64.

Mergia E, Thieme M, Hoch H, Daniil G, Hering L, Yakoub M, Scherbaum CR, Rump LC Koesling D, and Stegbauer J(2018) Impact of the NO-sensitive guanylyl cyclase 1 and 2 on renal blood flow and systemic blood pressure in mice. Int J Mol Sci 19.

Michelet R, Van Bocxlaer J, Allegaert K, and Vermeulen A(2018) The use of PBPK modeling across the pediatric age range using propofol as a case. J Pharmacokinet Pharmacodyn $\mathbf{4 5}$ 765-785.

Miki Y, Suzuki T, Tazawa C, Blumberg B, and Sasano H(2005) Steroid and xenobiotic receptor (SXR), cytochrome P450 3A4 and multidrug resistance gene 1 in human adult and fetal tissues. Mol Cell Endocrinol 231:75-85.

Moe L and Heiene R(1995) Estimation of glomerular filtration rate in dogs with 99M-Tc-DTPA and iohexol. Res Vet Sci 58:138-143.

Momper JD and Nigam SK(2018) Developmental regulation of kidney and liver solute carrier and ATP-binding cassette drug transporters and drug metabolizing enzymes: the role of remote organ communication. Expert Opin Drug Metab Toxicol 14:561-570.

Moore ES, Galvez MB, Paton JB, Fisher DE, and Behrman RE(1974) Effects of positive pressure ventilation on intrarenal blood flow in infant primates. Pediatr Res 8:792-796.

Nagata K, Ozawa S, Miyata M, Shimada M, Gong DW, Yamazoe Y, and Kato R(1993) Isolation and expression of a cDNA encoding a male-specific rat sulfotransferase that catalyzes activation of N-hydroxy-2-acetylaminofluorene. J Biol Chem 268:24720-24725.

Nagle MA, Truong DM, Dnyanmote AV, Ahn SY, Eraly SA, Wu W, and Nigam SK(2011) Analysis of three-dimensional systems for developing and mature kidneys clarifies the role of OAT1 and OAT3 in antiviral handling. $J$ Biol Chem 286:243-251.

Nakajima N, Sekine T, Cha SH, Tojo A, Hosoyamada M, Kanai Y, Yan K, Awa S, and Endou $\mathrm{H}(2000)$ Developmental changes in multispecific organic anion transporter 1 expression in the rat kidney. Kidney Int 57:1608-1616.

Neal-Kluever A, Fisher J, Grylack L, Kakiuchi-Kiyota S, and Halpern W(2019) Physiology of the neonatal gastrointestinal system relevant to the disposition of orally administered medications. Drug Metab Dispos 47:296-313.

Nomura M, Motohashi H, Sekine H, Katsura T, and Inui K(2012) Developmental expression of renal organic anion transporters in rat kidney and its effect on renal secretion of phenolsulfonphthalein. Am J Physiol Renal Physiol 302:F1640-F1649.

Oberley TD, Friedman AL, Moser R, and Siegel FL(1995) Effects of lead administration on developing rat kidney. II. Functional, morphologic, and immunohistochemical studies. Toxico Appl Pharmacol 131:94-107.

Olbing H, Blaufox MD, Aschinberg LC, Silkalns GI, Bernstein J, Spitzer A, and Edelmann CM Jr.(1973) Postnatal changes in renal glomerular blood flow distribution in puppies. J Clin Invest 52:2885-2895.

Omiecinski CJ, Aicher L, and Swenson L(1994) Developmental expression of human microsomal epoxide hydrolase. J Pharmacol Exp Ther 269:417-423.

Owen RA and Heywood R(1986) Age-related variations in renal structure and function in SpragueDawley rats. Toxicol Pathol 14:158-167.

Pacifici GM, Bencini C, and Rane A(1986) Acetyltransferase in humans: development and tissue distribution. Pharmacology 32:283-291.

Pacifici GM, Kubrich M, Giuliani L, de Vries M, and Rane A(1993) Sulphation and glucuronidation of ritodrine in human foetal and adult tissues. Eur J Clin Pharmacol 44:259-264.

Pacifici GM, Peng D, and Rane A(1983) Epoxide hydrolase and aryl hydrocarbon hydroxylase in human fetal tissues: activities in nuclear and microsomal fractions and in isolated hepatocytes. Pediatr Pharmacol (New York) 3:189-197.

Pavlova A, Sakurai H, Leclercq B, Beier DR, Yu AS, and Nigam SK(2000) Developmentally regulated expression of organic ion transporters NKT (OAT1), OCT1, NLT (OAT2), and Roct. Am J Physiol Renal Physiol 278:F635-F643.

Peeters MY, Allegaert K, Blussé van Oud-Alblas HJ, Cella M, Tibboel D, Danhof M, and Knibbe CA(2010) Prediction of propofol clearance in children from an allometric model developed in rats, children and adults versus a 0.75 fixed-exponent allometric model. Clin Pharmacokinet 49 269-275.
Pinto N, Halachmi N, Verjee Z, Woodland C, Klein J, and Koren G(2005) Ontogeny of renal P-glycoprotein expression in mice: correlation with digoxin renal clearance. Pediatr Res $\mathbf{5 8}$ $1284-1289$.

Prinzen FW and Bassingthwaighte JB(2000) Blood flow distributions by microsphere deposition methods. Cardiovasc Res 45:13-21.

Qi Z and Breyer MD(2009) Measurement of glomerular filtration rate in conscious mice, Kidney Research pp 61-72, Humana Press, New York.

Qi Z, Whitt I, Mehta A, Jin J, Zhao M, Harris RC, Fogo AB, and Breyer MD(2004) Serial determination of glomerular filtration rate in conscious mice using FITC-inulin clearance. Am J Physiol Renal Physiol 286:F590-F596.

Rabito CA, van Tongeren S, Zavorskas PA, Stricker-Krongrad A, Robb J, and Haupert GT Jr.(2010) Measurement of glomerular filtration rate in anesthetized and conscious rhesus monkeys (Macaca mulatta). Am J Vet Res 71:1492-1499.

Raijmakers MT, Steegers EA, and Peters WH(2001) Glutathione S-transferases and thiol concentrations in embryonic and early fetal tissues. Hum Reprod 16:2445-2450.

Ransley PG, Risdon RA, and Godley ML(1987) Effects of vesicoureteric reflux on renal growth and function as measured by GFR, plasma creatinine and urinary concentrating ability. An experimental study in the minipig. Br J Urol 60:193-204.

Rieg T (2013) A High-throughput method for measurement of glomerular filtration rate in conscious mice. $J$ Vis Exp 75:e50330.

Ritt M, Janka R, Schneider MP, Martirosian P, Hornegger J, Bautz W, Uder M, and Schmieder $R E(2010)$ Measurement of kidney perfusion by magnetic resonance imaging: comparison of MRI with arterial spin labeling to para-aminohippuric acid plasma clearance in male subjects with metabolic syndrome. Nephrol Dial Transplant 25:1126-1133.

Rodieux F, Wilbaux M, van den Anker JN, and Pfister M(2015) Effect of kidney function on drug kinetics and dosing in neonates, infants, and children. Clin Pharmacokinet 54:1183-1204.

Romero CA, Cabral G, Knight RA, Ding G, Peterson EL, and Carretero OA(2018) Noninvasive measurement of renal blood flow by magnetic resonance imaging in rats. Am J Physiol Renal Physiol 314:F99-F106.

Rubin MI, Bruck E, and Rapoport M(1949) Maturation of renal function in childhood: clearance studies. J Clin Invest 28:1144-1162.

Schmidt-Nielsen B and O'Dell R(1961) Structure and concentrating mechanism in the mammalian kidney. Am J Physiol 200:1119-1124.

Schuetz EG, Schuetz JD, Grogan WM, Naray-Fejes-Toth A, Fejes-Toth G, Raucy J, Guzelian P, Gionela K, and Watlington CO(1992) Expression of cytochrome P450 3A in amphibian, rat, and human kidney. Arch Biochem Biophys 294:206-214

Seely JC(2017) A brief review of kidney development, maturation, developmental abnormalities, and drug toxicity: juvenile animal relevancy. J Toxicol Pathol 30:125-133.

Shen AL, O'Leary KA, and Kasper CB(2002) Association of multiple developmental defects and embryonic lethality with loss of microsomal NADPH-cytochrome P450 oxidoreductase. J Biol Chem 277:6536-6541

Short KM, Combes AN, Lefevre J, Ju AL, Georgas KM, Lamberton T, Cairncross O, Rumballe BA, McMahon AP, Hamilton NA, et al.(2014) Global quantification of tissue dynamics in the developing mouse kidney. Dev Cell 29:188-202.

Sivarajan M, Amory DW, and Lindbloom LE(1976) Systemic and regional blood flow during epidural anesthesia without epinephrine in the rhesus monkey. Anesthesiology 45:300-310.

Skinner AV(2014) Neonatal pharmacology. Anaesth Intensive Care Med 15:7.

Slitt AL, Cherrington NJ, Hartley DP, Leazer TM, and Klaassen CD(2002) Tissue distribution and renal developmental changes in rat organic cation transporter mRNA levels. Drug Metab Dispos 30:212-219.

Solhaug MJ, Bolger PM, and Jose PA(2004) The developing kidney and environmental toxins. Pediatrics 113 (4 Suppl):1084-1091.

Sweeney DE, Vallon V, Rieg T, Wu W, Gallegos TF, and Nigam SK(2011) Functional maturation of drug transporters in the developing, neonatal, and postnatal kidney. Mol Pharmacol 80: $147-154$.

Sweet DH, Eraly SA, Vaughn DA, Bush KT, and Nigam SK(2006) Organic anion and cation transporter expression and function during embryonic kidney development and in organ culture models. Kidney Int 69:837-845.

Swindle MM and Brown DB(2016) Miniature Swine as Endo-Urological and Urological Models, Sinclair Research, Auxvasse, MO.

Takasu M, Tsuji E, Imaeda N, Matsubara T, Maeda M, Ito Y, Shibata S, Ando A, Nishii N, Yamazoe K, et al.(2015) Body and major organ sizes of young mature microminipigs determined by computed tomography. Lab Anim 49:65-70.

Tan H, Thacker J, Franklin T, and Prasad PV(2015) Sensitivity of arterial spin labeling perfusion MRI to pharmacologically induced perfusion changes in rat kidneys. J Magn Reson Imaging 41: $1124-1128$.

't Jong G(2014) Pediatric development: physiology, enzymes, drug metabolism, pharmacokinetics and pharmacodynamics, Pediatric Formulations, A Roadmap pp 9-24, Springer, New York.

Tolson AH and Wang H(2010) Regulation of drug-metabolizing enzymes by xenobiotic receptors: PXR and CAR. Adv Drug Deliv Rev 62:1238-1249.

Truong DM, Kaler G, Khandelwal A, Swaan PW, and Nigam SK(2008) Multi-level analysis of organic anion transporters 1,3 , and 6 reveals major differences in structural determinants of antiviral discrimination. $J$ Biol Chem 283:8654-8663.

van Kalken CK, Giaccone G, van der Valk P, Kuiper CM, Hadisaputro MM, Bosma SA, Schepe RJ, Meijer CJ, and Pinedo HM(1992) Multidrug resistance gene (P-glycoprotein) expression in the human fetus. Am J Pathol 141:1063-1072.

van Liew JB, Deetjen P, and Boylan JW(1967) Glucose reabsorption in the rat kidney. Dependence on glomerular filtration. Pflugers Arch Gesamte Physiol Menschen Tiere 295:232-244.

Vieux R, Desandes R, Boubred F, Semama D, Guillemin F, Buchweiller MC, Fresson J, and Hascoet $\operatorname{JM}(2010)$ Ibuprofen in very preterm infants impairs renal function for the first month of life. Pediatr Nephrol 25:267-274.

Visser MO, Leighton JO, van de Bor M, and Walther FJ(1992) Renal blood flow in neonates: quantification with color flow and pulsed Doppler US. Radiology 183:441-444.

Von Hendy-Willson VE and Pressler BM(2011) An overview of glomerular filtration rate testing in dogs and cats. Vet $J$ 188:156-165.

Wang H and Tompkins LM(2008) CYP2B6: new insights into a historically overlooked cytochrome P450 isozyme. Curr Drug Metab 9:598-610.

Watson AD, Lefebvre HP, Concordet D, Laroute V, Ferré JP, Braun JP, Conchou F, and Toutain PL(2002) Plasma exogenous creatinine clearance test in dogs: comparison with other methods and proposed limited sampling strategy. J Vet Intern Med 16:22-33. 
West JR, Smith HW, and Chasis H(1948) Glomerular filtration rate, effective renal blood flow, and maximal tubular excretory capacity in infancy. $J$ Pediatr 32:10-18.

Wilkins BH(1992) Renal function in sick very low birthweight infants: 1. Glomerular filtration rate Arch Dis Child 67:1140-1145.

Witte MK, Stork JE, and Blumer JL(1986) Diuretic therapeutics in the pediatric patient. Am $J$ Cardiol 57:44A-53A.

Wu L, Gu J, Weng Y, Kluetzman K, Swiatek P, Behr M, Zhang QY, Zhuo X, Xie Q, and Ding $\mathrm{X}(2003)$ Conditional knockout of the mouse NADPH-cytochrome $\mathrm{p} 450$ reductase gene. Genesis 36:177-181

Xiangrong L, Jöhnk C, Hartmann D, Schestag F, Krömer W, and Gieselmann V(2000) Enzymatic properties, tissue-specific expression, and lysosomal location of two highly homologous rat SULT1C2 sulfotransferases. Biochem Biophys Res Commun 272:242-250.

Xu YJ, Wang Y, Lu YF, Xu SF, Wu Q, and Liu J(2017) Age-associated differences in transporter gene expression in kidneys of male rats. Mol Med Rep 15:474-482.

Yu W, Sandoval RM, and Molitoris BA(2007) Rapid determination of renal filtration function using an optical ratiometric imaging approach. Am J Physiol Renal Physiol 292:F1873-F1880.
Zhang C, Ding S, Fang Y, Zhang L, Hu W, Lu J, Jing T, Tao Y, and Zhang X(2017) Iohexol clearance for determination of glomerular filtration rate in cynomolgus monkeys (Macaca fascicularis). J Am Assoc Lab Anim Sci 56:330-333.

Zimmer F, Zöllner FG, Hoeger S, Klotz S, Tsagogiorgas C, Krämer BK, and Schad LR(2013) Quantitative renal perfusion measurements in a rat model of acute kidney injury at 3T: testing inter- and intramethodical significance of ASL and DCE-MRI. PLoS One 8:e53849.

Zoetis T and Hurtt ME(2003) Species comparison of anatomical and functional renal development. Birth Defects Res B Dev Reprod Toxicol 68:111-120.

Address correspondence to: Dr. Ruud Bueters, Janssen Research \& Development, a division of Janssen Pharmaceutica NV, Division of Discovery, Product Development \& Supply, Department of Nonclinical Safety, Turnhoutseweg 30, 2340 Beerse, Belgium. E-mail: rbueters@its.jnj.com 